\title{
Potential High-Tech Clusters in Russian Regions: From Current Policy to New Growth Areas
}

\author{
Stepan Zemtsov \\ Senior Research Fellow, Laboratory for Research on Corporate Strategies and Firm Behaviour Studies.
} E-mail: zemtsov@ranepa.ru

Vera Barinova

Head, Laboratory for research on corporate strategies and firm behaviour studies. E-mail: barinova-va@ranepa.ru

Institute of Applied Economic Research, Russian Presidential Academy of National Economy and Public Administration under the President of the Russian Federation (RANEPA). Address: 82 / 1, Vernadsky prospekt, Moscow 119571, Russian Federation

\begin{abstract}
Alexey Pankratov
Graduate Student, Department of Economic and Social Geography of Russia, Faculty of Geography, Moscow State University. Address: Moscow State University, Faculty of Geography, GSP-1, Lenin Hills, Moscow 119991, Russian Federation.E-mail: pankratov_aleksey_ml@mail.ru
\end{abstract}

\section{Evgeniy Kutsenko}

Head, Cluster Policy Department, Institute for Statistical Studies and Economics of Knowledge, National Research University Higher School of Economics. Address: 11, Myasnitskaya str., Moscow 101000, Russian Federation. E-mail: ekutsenko@hse.ru

\begin{abstract}
$\mathrm{I}^{\mathrm{n}}$

$\mathrm{n}$ the current climate of sanctions imposed against Russia by several countries in 2014, special attention should be given to high-tech sectors of the economy as a key source of import substitution on the domestic market. One of the important policy measures is to support the development of high-tech, specialized clusters by forming new linkages and strengthening existing ones between small and medium-sized businesses, large enterprises, and research organizations. The starting point for an effective cluster policy is to define areas with high potential for

clustering of these industries. The paper presents an original method to identify potential clusters and tests the method on Russian regions. We show that most of the state-supported pilot innovative territorial clusters are being developed in regions and sectors that have a high level of cluster potential. A typology of existing clusters depends on the index of clustering potential. We identified regions that have similar or comparatively favourable conditions for creating clusters in the pilot sectors.
\end{abstract}

Keywords: clusters; small and medium enterprises; location quotients; pilot innovative clusters; regions; Russia; hightech industries

DOI: 10.17323/1995-459X.2016.3.34.52
Citation: Zemtsov S., Barinova V., Pankratov A., Kutsenko E. (2016) Potential High-Tech Clusters in Russian Regions: From Current Policy to New Growth Areas. Foresight and STI Governance, vol. 10, no 3, pp. 34-52. DOI: 10.17323/1995-459X.2016.3.34.52 
$\mathrm{C}$ luster policy is a major component of the current Russian innovation-based development agenda. In early 2012, the Russian Ministry of Economic Development launched a tender for projects on setting up pilot innovative territorial clusters (ITCs) in Russian regions. 25 cluster initiatives were selected to receive public funding out of about a hundred applications. Most of the approved projects aimed to develop innovation infrastructure [Gokhberg, Shadrin, 2015; Kutsenko, 2015; Zemtsov et al., 2015; Bortnik et al., 2015], which (unlike integrated cluster development programmes) did not imply research and development (R\&D), innovation activities, staff (re)training, and other major initiatives. ${ }^{1}$ Many Russian regions proclaim that the creation of clusters and providing support to them are priorities of their socioeconomic development strategies. The objective here is usually to restructure core enterprises, establish a network of suppliers around them, promote the development of small and medium high-technology companies, and step up cooperation between businesses, R\&D, and educational organizations. Many cluster initiatives emerge from the 'bottom-up', and frequently remain unnoticed by regional or federal authorities.

The principles of companies' territorial concentration have been studied for quite a long time. Alfred Marshall provided a detailed description of the so-called 'localised industry' during the pre-industrial era [Marshall, 1920], when companies belonging to certain groups of industries were located in relative proximity to each other thus forming highly competitive industrial circles. More recent studies of a similar nature analyse clusters of enterprises as 'geographically concentrated groups of interdependent companies, specialized suppliers, service providers, and affiliated organizations (including universities, R\&D organizations, etc.), in manufacturing or service sectors' [Porter, 2008].

Recent international studies show that being part of a cluster helps companies because it simplifies access to specialized production factors and labour, specific knowledge, and competencies [Porter, 1998; 2008; Karlsson, 2008]. New businesses are created more quickly in clusters [Bresnahan et al., 2001; Feldman et al., 2005]; they have better chances to survive [Staber, 2001; Wennberg, Lindqvist, 2010]; the share of exporting companies is higher [Bair, Gereffi, 2001]; firms' economic performance is better [Zhang, Li, 2008], and they innovate more actively [Cooke, Schwartz, 2007].

Clusters only became a focus of government policy in the 1990s, not counting similar but different formations such as territorial production complexes [Pilipenko, 2004], growth poles, and other entities. The subsequent proliferation of clusters is primarily due to the work of Michael Porter [Porter, 2008]. The approach he suggested included recommendations to increase competitiveness for many countries, including Russia [Porter, Ketels, 2007]. Today, cluster policies are most actively implemented by the European Union member states (Germany, France, Spain, Austria, Czech Republic) [Ketels, 2003; Ketels et al., 2012] and Latin American countries (Mexico, Brazil, Chile, Colombia). Numerous studies of cluster policies have been conducted in the previous two decades, setting out recommendations for cluster policies [Kutsenko, 2015].

A key issue in cluster policy is the feasibility of government intervention in clustering processes, and the limits of such actions. Many in the professional community believe that clusters emerge through a natural process, which governments can only hinder [Martin et al., 2008; Duranton, 2011]. In [van der Linde, 2003], only one of the more than 700 studied clusters (in Xīnzhú Shì, Taiwan) can be unequivocally considered to be a result of targeted government policy. On the other hand, it is hard to find a cluster that has not received any government support in any form. Some, such as the creative industry clusters in the $\mathrm{UK}$, are totally dependent on public funding [Landry, 2008].

An efficient cluster policy implies providing balanced support, which would help deal with 'market failures' on the one hand and also would not result in government failures. The latter can include setting the wrong priorities or erroneously choosing recipients to support, a mismatch between regulation tools and the nature of problems, lobbying by pressure groups, etc. These can render all government's efforts in this sphere pointless (for more information, see [Kutsenko, 2012]). Many such errors are often found in policies pursued by many groups of countries. For example, certain regional development strategies in the EU have a low level of interdepartmental cooperation; are focused on R\&D at the expense of analysing actual market demand; favour traditional industries over newly emerging ones; and give too much importance to prestigious projects and subject areas [Sörvik, Midtkandal, 2013].

Recent decades have seen growing demand for projects to identify and evaluate areas with the highest potential for regional-level cluster development. First, we mean the above-mentioned project headed by Michael Porter in the US [Porter, 2003; Delgado et al., 2014], and the activities of the European Cluster Observatory [Ketels, Protsiv, 2014a; Ketels, Protsiv, 2014b]. Based on the latter's methodology, a pilot

\footnotetext{
${ }^{1}$ Draft list of pilot development programmes for innovative territorial clusters, with relevant analytical materials, dated 05.07 .2012 No 135175-AK/D-19ч. Available at: http://economy.gov.ru/wps/wcm/connect/1a5dcd004bf64bef858d9d77bb90350d/doklad_ proekt.pdf?MOD=AJPERES, last accessed on 26.07.2016.
} 
project to identify priority industries and regions for setting up clusters in Russia was implemented in the late 2000s [Kutsenko, 2009; Kutsenko et al., 2011; Danko, Kutsenko, 2012]. In 2015, the Russian Cluster Observatory launched the Cluster Initiatives Map with detailed accumulated information about the approximately 100 clusters which provided relevant data. ${ }^{2}$

If government policies and support initiatives match the actual specialization areas of regions with the highest cluster development potential, the risks of pursuing an inefficient cluster policy are lessened. However, advanced tools to identify prospective development areas are applied relatively rarely. For example, only localization coefficients were used in the Upper Austria region to select clusters for government support [Pamminger, 2014]. However, even such relatively simple instruments significantly reduce the risks. We are not aware of any efforts to directly apply specialized tools to identify prospective industries in any Russian region that supports clusters. The development and testing of such tools hence seems to be a relevant practical step to increase the effectiveness of Russia's cluster policy. Other important success factors of such policies, which should be considered when selecting clusters, include the following:

- The predominance of private initiatives [INNO Germany AG, 2010, p. 108; Hagenauer et al., 2012, p. 2; Abashkin et al., 2012; Lindqvist et al., 2013; Kutsenko, 2015];

- The prioritization of small and medium businesses' interests [Dohse, Staehler, 2008; Eickelpasch, 2008; DGCIS, 2009; Pro Inno Europe, 2009; Christensen et al., 2012; Lindqvist et al., 2013];

- A wide range of cluster participants and promoting competition (not just cooperation) between them [Porter, 1998; Pamminger, 2014; Kutsenko, 2015].

One of the major drawbacks of the Russian pilot ITCs is, in our opinion, the insignificant number of small enterprises in them, and their insufficient interactions. Small enterprises are most interested in joining clusters, as well as in planning and implementing joint projects. Coordinating on projects means they can consolidate resources to deal with common problems that would be unsolvable by any single company on its own. According to our calculations, the share of small and medium companies in the total number of pilot clusters' participants is much lower than in European countries [Zemtsov et al., 2015; Bortnik et al., 2015]. In international projects to identify clusters, the above-mentioned factors are not currently taken into account directly. In other words, there is a gap between theoretical knowledge on the one hand, and providing expert support to decision makers on the other.

The objective of this study is to make a methodological contribution to identify industries with the highest cluster development potential regionally. Complementary to other factors such as the level of competition and support for small businesses, our proposed methodology will be tested by comparing indices reflecting the clustering potential of Russian regions in selected economic activity types with data on the location of pilot clusters selected for support by the Russian Ministry of Economic Development.

\section{Data sources and methodology}

Special clustering indices were calculated to identify industries with high clustering potential. To this end, we applied the following algorithm based on the European Cluster Observatory's methodology [Zemtsov, Bukov, 2016]. In the first stage, all Russian pilot ITCs were broken down by high-tech industries ${ }^{3}$ in accordance with their main specialization ${ }^{4}$ based on the Russian classification of economic activities, called OKVED (Table 1). Note that some clusters specialize in several high-tech industries. Statistics collected for all selected economic activities matching the specialization of pilot ITCs show the number of companies operating in various Russian regions in 2013, their revenues, and total number of employees. Calculations were based on data available in the SPARK ${ }^{5}$ and RUSLANA ${ }^{6}$ databases.

In the second stage, we estimated each company's share of total revenues, and the total number of employees of all firms specializing in the selected industries in each Russian region. Based on these

\footnotetext{
2 See http://map.cluster.hse.ru; last accessed on 16.06.2016.

${ }^{3}$ According to Rosstat's classification [Rosstat, 2014] based on the OECD and Eurostat recommendations, high-tech industries include the following OKVED groups: 24.4. Production of pharmaceutical products; 30 . Production of office equipment and computers; 32. Production of electronic components, radio, TV, and communication hardware; 33 . Production of medical products; measuring, control, and testing instruments; optical instruments, photographic and cinematic equipment; watches; 35.3 . Production of aircrafts and spacecrafts. Other ITC industries such as petrochemical, automobile, and shipbuilding, are classified as medium-technology. ICT (code 72) is included in research-intensive activities.

${ }^{4}$ According to the Russian Cluster Observatory data. Available at: http://cluster.hse.ru/, last accessed on 16.06.2016.

${ }^{5}$ SPARK is a professional market and business analytics system. Available at: http://www.spark-interfax.ru/Front/Index.aspx, accessed on 16.06.2016.

6 RUSLANA is a database with information about Russian, Ukrainian, and Kazakh companies. Available at: https://ruslana.bvdep. com/, last accessed on 16.06.2016.
} 


\section{Table 1. High-technology industrial specializations of Russian pilot innovative territorial} clusters in regions (based on 2013 data)

\begin{tabular}{|c|c|}
\hline $\begin{array}{l}\text { Industries (according to OKVED } \\
\text { classification) }\end{array}$ & $\begin{array}{c}\text { Innovative territorial clusters (regions and cities where cluster participants } \\
\text { are primarily located) }\end{array}$ \\
\hline \multicolumn{2}{|r|}{ 1. Pharmaceuticals and biotechnology } \\
\hline \multirow{4}{*}{$\begin{array}{l}\text { Production of pharmaceutical } \\
\text { products }(244)\end{array}$} & Biopharmaceutical cluster (Altai Region: Barnaul, Biysk) \\
\hline & Pharmaceuticals, biotechnology, and biomedicine cluster (Kaluga Region: Obninsk) \\
\hline & Biotechnology innovative territorial cluster (Moscow Region: Pushchino) \\
\hline & Nuclear physics and nanotechnology innovative territorial cluster (Moscow Region: Dubna) \\
\hline \multirow{4}{*}{$\begin{array}{l}\text { Production of medical products } \\
\text { including surgical equipment and } \\
\text { orthopaedic appliances (331) }\end{array}$} & PhysTech XXI cluster (Moscow Region: Dolgoprudny, Khimki) \\
\hline & $\begin{array}{l}\text { Information and biopharmaceutical technologies innovative cluster (Novosibirsk Region: } \\
\text { Novosibirsk) }\end{array}$ \\
\hline & Medical, pharmaceutical, and radiation technologies cluster (St. Petersburg, Leningrad Region) \\
\hline & Pharmaceuticals, medical equipment, information technologies (Tomsk Region: Tomsk) \\
\hline \multicolumn{2}{|r|}{ 2. Information and communication technologies } \\
\hline \multirow{5}{*}{$\begin{array}{l}\text { Activities involving application } \\
\text { of computers and information } \\
\text { technologies }(72)\end{array}$} & PhysTech XXI cluster (Moscow Region: Dolgoprudny, Khimki) \\
\hline & Sarov innovative cluster (Nizhny Novgorod Region: Sarov) \\
\hline & $\begin{array}{l}\text { Information and biopharmaceutical technologies innovative cluster (Novosibirsk Region: } \\
\text { Novosibirsk) }\end{array}$ \\
\hline & $\begin{array}{l}\text { Development of information technologies, radio-electronics, instruments, communication } \\
\text { equipment, info-telecommunications (St. Petersburg) }\end{array}$ \\
\hline & Pharmaceuticals, medical equipment, information technologies (Tomsk Region: Tomsk) \\
\hline \multicolumn{2}{|r|}{ 3. Aerospace technologies } \\
\hline \multirow{5}{*}{$\begin{array}{l}\text { Production of aircrafts and } \\
\text { spacecrafts (353) }\end{array}$} & ZATO innovative technologies cluster (Krasnoyarsk Region: Zheleznogorsk) \\
\hline & Aerospace cluster (Samara Region: Samara) \\
\hline & $\begin{array}{l}\text { Novy Zvezdny Technopolis rocket propulsion engineering innovative territorial cluster (Perm } \\
\text { Region: Perm) }\end{array}$ \\
\hline & Ulyanovsk-Avia research, education, and production cluster (Ulyanovsk Region: Ulyanovsk) \\
\hline & $\begin{array}{l}\text { Aircraft construction and shipbuilding innovative territorial cluster (Khabarovsk Region: } \\
\text { Khabarovsk, Komsomolsk-on-Amur) }\end{array}$ \\
\hline \multicolumn{2}{|r|}{ 4. Petrochemical industry } \\
\hline Production of oil products (232) & $\begin{array}{l}\text { Nizhniy Novgorod automobile and petrochemical industrial innovative cluster (Nizhniy } \\
\text { Novgorod Region: Nizhniy Novgorod, Kstovo) }\end{array}$ \\
\hline \multirow[t]{2}{*}{ Production of rubber products (251) } & Petrochemical territorial cluster (Republic of Bashkortostan) \\
\hline & $\begin{array}{l}\text { Kama innovative territorial production cluster (Republic of Tatarstan: Naberezhnye Chelny, } \\
\text { Nizhnekamsk, Elabuga) }\end{array}$ \\
\hline \multicolumn{2}{|r|}{ 5. Instruments and electronics } \\
\hline \multirow[t]{2}{*}{$\begin{array}{l}\text { Production of electrical machinery } \\
\text { and equipment (31) }\end{array}$} & $\begin{array}{l}\text { Energy-saving lighting equipment and smart lighting control systems (Republic of Mordovia: } \\
\text { Saransk) }\end{array}$ \\
\hline & Zelenograd cluster (Moscow: Zelenograd) \\
\hline $\begin{array}{l}\text { Production of electronic components, } \\
\text { radio, TV, and communication } \\
\text { hardware (32) }\end{array}$ & $\begin{array}{l}\text { Development of information technologies, radio-electronics, instruments, communication } \\
\text { equipment, info-telecommunications (St. Petersburg) }\end{array}$ \\
\hline \multicolumn{2}{|r|}{ 6. Shipbuilding } \\
\hline \multirow[b]{2}{*}{ Shipbuilding and ship repair (351) } & Shipbuilding innovative territorial cluster (Archangel Region: Archangel, Severodvinsk) \\
\hline & $\begin{array}{l}\text { Aircraft construction and shipbuilding innovative territorial cluster (Khabarovsk Region: } \\
\text { Khabarovsk, Komsomolsk-on-Amur) }\end{array}$ \\
\hline \multicolumn{2}{|r|}{ 7. Automobile industry } \\
\hline \multirow[t]{2}{*}{$\begin{array}{l}\text { Production of automobiles, trailers, } \\
\text { and semi-trailers (34) }\end{array}$} & $\begin{array}{l}\text { Nizhniy Novgorod automobile and petrochemical industrial innovative cluster (Nizhniy } \\
\text { Novgorod Region: Nizhniy Novgorod, Kstovo) }\end{array}$ \\
\hline & $\begin{array}{l}\text { Kama innovative territorial production cluster (Republic of Tatarstan: Naberezhnye Chelny, } \\
\text { Nizhnekamsk, Elabuga) }\end{array}$ \\
\hline Source: compiled by the authors. & \\
\hline
\end{tabular}


data, we calculated a coefficient of monopolization of the industry for each region, having removed the possible distorting impacts of a single company dominating the local market:

$H H^{\text {Emp }}{ }_{i, g}=\sum_{n_{i, g}} S_{f, i, g}^{2}{ }^{\text {Emp }}$
$H H^{\text {Sale }}{ }_{i, g}=\sum_{n_{i, g}} S_{f, i, g}^{2} \quad$ Sale

Where:

$\mathrm{HH}$ - monopolization (or concentration) factor ${ }^{7}$ (Herfindahl-Hirschman Index) for industry $i$ in region $g$; $n$ - number of companies specializing in the industry in the region;

$s-$ share of company $f$

Emp - number of employees;

Sale - revenue (million roubles)

The opposite indicator $(1-H H)$ may be called the deconcentration index: the higher its value, the lower the monopolization level of the regional economy.

In the third stage, localization factors were calculated for the relevant industries in each region using three parameters: the number of companies, revenues, and the number of employees. Three characteristics were used for mutual verification purposes:

$L Q_{i, g}^{\text {Firm }}=\frac{\text { Firm }_{i, g}}{\text { Firm }_{g}} / \frac{\text { Firm }_{i, R}}{\text { Firm }_{R}}$

$L Q^{E m p_{i, g}}=\frac{E m p_{i, g}}{E m p_{g}} / \frac{E m p_{i, R}}{E m p_{R}}$

$L Q^{\text {Sale }_{i, g}}=\frac{\text { Sale }_{i, g}}{\text { Sale }_{g}} / \frac{\text { Sale }_{i, R}}{\text { Sale }_{R}}$

Where:

$L Q-$ localization factor for industry $i$ in region $g$;

Firm - number of companies;

$R-$ Russian average value of the indicator.

In the fourth stage, the relative sizes of the regional industries (Size) were calculated i.e. the total relevant regional companies' share in the total value of the industry's indicator for the national economy.

Size $^{\text {Firm }}{ }_{i, g}=\frac{\text { Firm }_{i, g}}{\text { Firm }_{i, R}}$

$\operatorname{Size}^{E m p}{ }_{i, g}=\frac{E m p_{i, g}}{E m p_{i, R}}$

Size $_{i, g}^{\text {Sale }}=\frac{\text { Sale }_{i, g}}{\text { Sale }_{i, R}}$

In the fifth stage, we normalized the calculation results using a linear scaling formula to reduce the indicator values to the $[0 ; 1]$ interval in order to ensure their compatibility.

$\operatorname{Ind}_{i, g}=\frac{\left(\operatorname{In} c_{i, g}-\min \left(\operatorname{In} c_{i, g}\right)\right)}{\left(\max \left(\operatorname{In} c_{i, g}\right)-\min \left(\operatorname{In} c_{i, g}\right)\right)}$

Where:

Ind - normalized index of industry $i$ in region $g$ for characteristic Inc: number of companies, employment, and revenues.

In the sixth stage, we calculated the Clustering Potential sub-index for each characteristic.

${ }^{7}$ Index values greater than 0.25 indicate a highly concentrated regional market. 
Cluster_subind ${ }_{i, g}^{\text {Firm }}=1 / 2\left(\operatorname{Ind}\left(\operatorname{LQ}_{i, g}^{\text {Firm }}{ }_{i, g}\right)+\operatorname{Ind}\left(\operatorname{Size}^{\text {Firm }}\right)\right) \times \operatorname{Ind}_{i, g}^{\text {Firm }}$

Cluster_subind ${ }_{i, g}^{E m p}=1 / 2\left(\operatorname{Ind}\left(L Q^{E m p}{ }_{i, g}\right)+\operatorname{Ind}\left(\operatorname{Size}^{E m p}\right)\right) \times n d\left(1-H H_{i, g}^{E m p}\right)$

Cluster_subind ${ }_{i, g}^{\text {Sale }}=1 / 2\left(\operatorname{Ind}\left(L Q_{i, g}^{\text {Sale }}\right)+\operatorname{Ind}\left(\operatorname{Size}^{\text {Sale }}\right)\right) \times \operatorname{Ind}\left(1-H H_{i, g}^{\text {Sale }}\right)$

Where:

Cluster_subind ${ }^{\text {Firm }}$ - clustering sub-index of industry $i$ in region $g$, based on the number of companies;

Ind ${ }^{\text {Firm }}$ - index measuring the number of companies specializing in industry $i$ in region $g^{8}$;

Cluster_subind ${ }^{E m p}$ — clustering sub-index based on the number of companies' employees;

Cluster_subind ${ }^{\text {Sale }}$ — clustering sub-index based on companies' revenues.

Finally, in the seventh stage, the Integral Clustering Potential index was calculated:

Cluster_Ind ${ }_{i, g}=1 / 3\left(\right.$ Cluster_subind ${ }_{i, g}^{\text {Firm }}+$ Cluster_subind ${ }_{i, g}^{\text {Emp }}+$ Cluster_subind $\left._{i, g}^{\text {Sale }}\right)$

Where: Cluster_Ind - an index of the clustering potential of industry $i$ in region $g$.

The Clustering Potential index describes the conditions for the emergence of clusters taking into account the industry and regional characteristics. This index enables state support to be based on a more rigorous (in an objective and methodical sense) method for selecting clusters.

\section{Verifying the selection of innovative clusters in Russia}

We calculated the clustering potential indices for all regions with pilot ITCs according to the industrial specialization, and subsequently compared them with other Russian regions. This enabled us to check whether the selected ITCs were located in regions with the highest values of the above-mentioned index. In addition, this procedure allowed us to identify new regions where similar high-tech clustering initiatives could be efficiently supported.

\section{Pharmaceuticals and biotechnology}

Thanks to many small and medium enterprises, ${ }^{9}$ the Russian pharmaceutical industry is one of the most promising industries from the perspective of cluster policy. The averaged deconcentration index for the industry (formulas (1) and (2)) in the supported regions exceeds 0.75 (Table 2). Six pilot clusters are supported in this field - the highest number among all industries.

About 1,500 companies are operating in the city of St. Petersburg and the surrounding Leningrad Region. The leaders of the pharmaceutical industry are Polysan, Biocad, Vertex, Geropharm, etc.; leading producers of medical equipment include Electron, ASK-Rentgen, Thermo Fisher Scientific, Trives. Among ITC participants, we also see some R\&D organizations such as the Yefremov Institute of Electrophysical Instruments, St. Petersburg State Chemical and Pharmaceutical Academy, the S\&T Centre RATEC, and others.

Unsurprisingly, the highest clustering potential index was measured in the city of Moscow (Figure 1) which has 4,177 companies - producers and suppliers of pharmaceuticals and medical equipment. Here, the industry's deconcentration index is 0.97. Several large companies operate in the city, such as the Moscow Pharmaceutical Factory, Semashko Moskhimpharmpreparaty, Bryntsalov-A Co., and several other high-tech firms. Among medical equipment producers, the Kazakov Moscow Instrumentation Plant and Unimed deserve a special note.

We also note a high concentration of companies specializing in this industry in the following regions:

- Nizhny Novgorod region: 275 companies, the largest being Nizhpharm, the Nizhny Novgorod Chemical and Pharmaceutical Factory;

- Sverdlovsk region: 306 companies, the largest of which is MEDTECHNIKA;

- Republic of Tatarstan: 306 companies, of which the largest is the Kazan Medical Instruments Plant.

\section{Information and communication technologies}

Five ITCs were selected in the ICT sector. The low industry concentration index indicates favourable conditions for implementing cluster initiatives (Table 3).

\footnotetext{
${ }^{8}$ This index is calculated on the basis of the number of companies using formula (9), but if there are $>100$ companies specializing in industry $i$ operating in the region, the index is assigned the value of 1 because that many companies are certainly enough to form a cluster. The value 100 was chosen as the minimum number of companies required for clustering.

${ }^{9}$ Many companies in the industry are packaging enterprises and drugstores producing perishable drugs; this must be taken into account when interpreting the results.
} 


\section{Figure 1. Integral Clustering Potential Index of the Russian pharmaceutical industry (2013 data)}

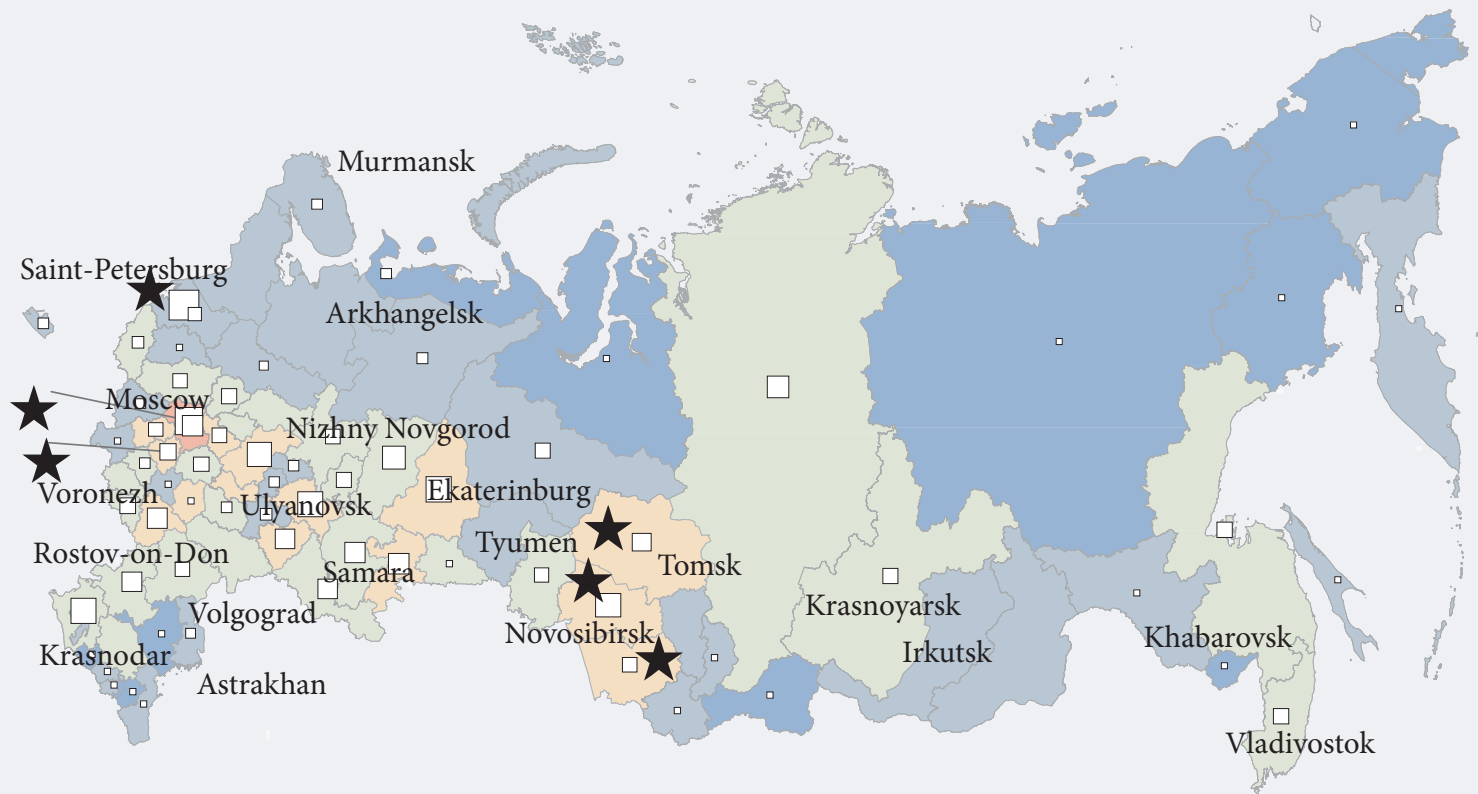

Integral Clustering Potential Index
$>0.4$
$0.201-0.4$
$0.101-0.2$
$0.051-0.1$
$0.011-0.05$
$0-0.01$

Number of companies in the region specializing in the industry
$\square>500$
$\square 201-500$
$\square 101-200$
$\square 51-100$
$\square 26-50$
$\square 0-25$

Note: Here and subsequently, existing pilot ITCs are marked with stars.

Source: compiled by the authors.

\section{Table 2. Clustering potential of the pharmaceutical industry in Russian regions}

\begin{tabular}{|c|c|c|c|c|c|c|c|c|c|}
\hline Region & $\begin{array}{c}\text { Num- } \\
\text { ber of } \\
\text { com- } \\
\text { panies }\end{array}$ & $\begin{array}{c}\text { Number } \\
\text { of em- } \\
\text { ployees }\end{array}$ & $\begin{array}{c}\begin{array}{c}\text { Cluster } \\
\text { diversifi- } \\
\text { cation by } \\
\text { number of } \\
\text { employ- } \\
\text { ees }\end{array} \\
\end{array}$ & $\begin{array}{l}\text { Com- } \\
\text { panies' } \\
\text { revenues } \\
\text { (million } \\
\text { roubles) }\end{array}$ & $\begin{array}{l}\text { Cluster } \\
\text { diversif- } \\
\text { cation by } \\
\text { revenue }\end{array}$ & $\begin{array}{c}\text { Number } \\
\text { of compa- } \\
\text { nies sub- } \\
\text { index }\end{array}$ & $\begin{array}{c}\text { Employ- } \\
\text { ment } \\
\text { Cluster- } \\
\text { ing sub- } \\
\text { index }\end{array}$ & $\begin{array}{l}\text { Revenue } \\
\text { Cluster- } \\
\text { ing sub- } \\
\text { index }\end{array}$ & $\begin{array}{l}\text { Integral } \\
\text { Clustering } \\
\text { Potential } \\
\text { index }\end{array}$ \\
\hline \multicolumn{10}{|c|}{ Regions with pilot ITCs } \\
\hline $\begin{array}{l}\text { St. Petersburg / Leningrad } \\
\text { Region }\end{array}$ & 1433 & 14087 & 0.97 & 11574 & 0.96 & 0.67 & 0.28 & 0.16 & 0.37 \\
\hline $\begin{array}{l}\text { Moscow Region } \\
\text { (Pushchino; PhysTech XXI) }\end{array}$ & 686 & 12423 & 0.97 & 9586 & 0.96 & 0.41 & 0.25 & 0.15 & 0.27 \\
\hline Kaluga Region & 94 & 1858 & 0.89 & 949 & 0.80 & 0.32 & 0.16 & 0.05 & 0.18 \\
\hline Tomsk Region & 119 & 1214 & 0.70 & 647 & 0.81 & 0.36 & 0.08 & 0.04 & 0.16 \\
\hline Novosibirsk Region & 249 & 3838 & 0.93 & 2226 & 0.89 & 0.23 & 0.13 & 0.06 & 0.14 \\
\hline Altai Region & 92 & 2725 & 0.81 & 527 & 0.94 & 0.17 & 0.13 & 0.04 & 0.11 \\
\hline \multicolumn{10}{|c|}{ Regions with clustering potential } \\
\hline City of Moscow & 4177 & 44874 & 0.98 & 50349 & 0.96 & 1.00 & 0.61 & 0.51 & 0.71 \\
\hline \begin{tabular}{|l|} 
Vladimir Region \\
\end{tabular} & 79 & 3618 & 0.85 & 1098 & 0.82 & 0.18 & 0.29 & 0.09 & 0.19 \\
\hline Tambov Region & 20 & 2263 & 0.65 & 2295 & 0.56 & 0.02 & 0.27 & 0.24 & 0.18 \\
\hline Nizhniy Novgorod Region & 275 & 3521 & 0.89 & 2687 & 0.92 & 0.32 & 0.13 & 0.07 & 0.17 \\
\hline Republic of Tatarstan & 306 & 3865 & 0.76 & 2229 & 0.94 & 0.31 & 0.11 & 0.05 & 0.16 \\
\hline Sverdlovsk Region & 306 & 4023 & 0.91 & 3398 & 0.94 & 0.25 & 0.11 & 0.07 & 0.14 \\
\hline \begin{tabular}{|l} 
Voronezh Region \\
\end{tabular} & 142 & 1398 & 0.89 & 957 & 0.89 & 0.25 & 0.06 & 0.04 & 0.12 \\
\hline
\end{tabular}




\section{Figure 2. Integral Clustering Potential Index of the Russian ICT sector (2013 data)}

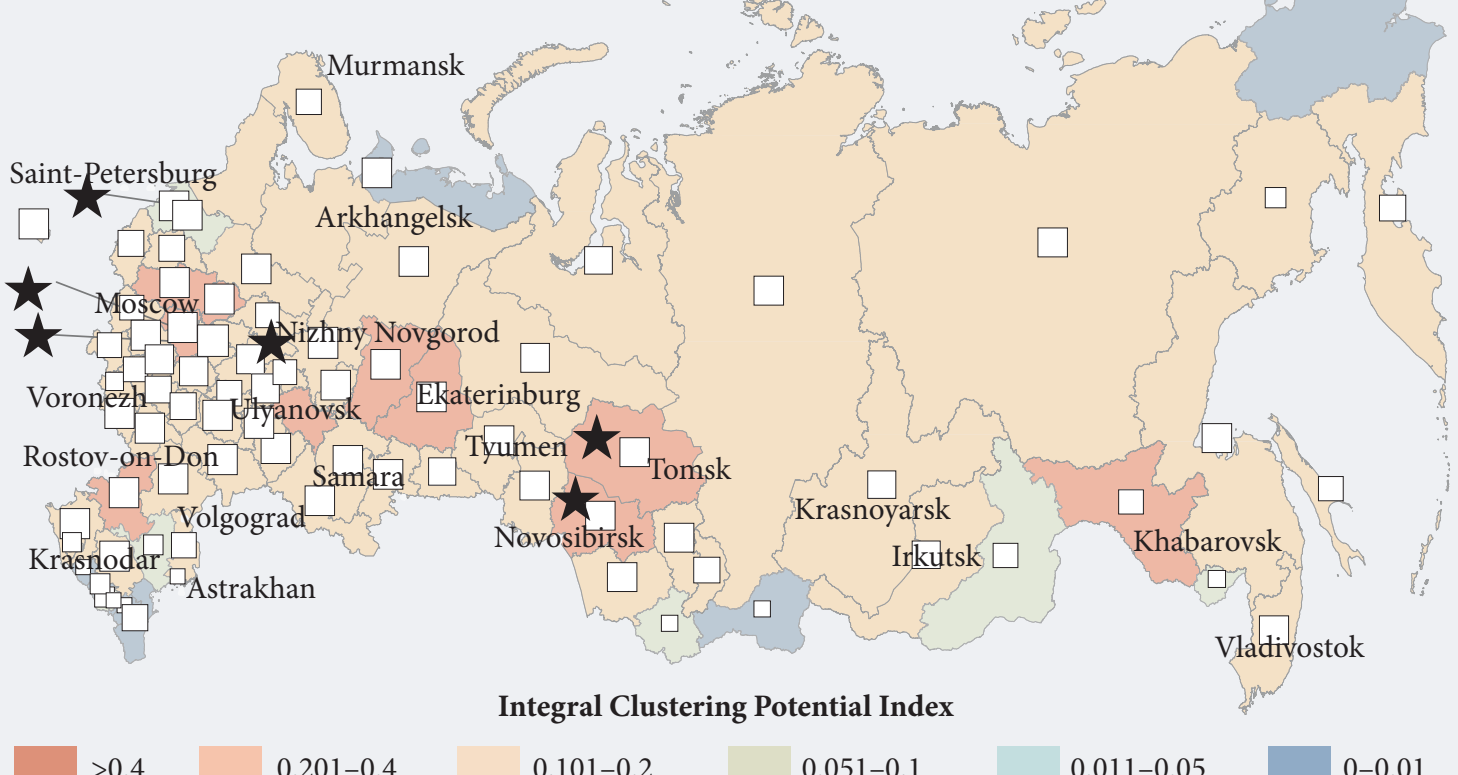

Number of companies in the region specializing in the industry
$\square>500$
$\square 201-500$
$\square 101-200$
$\square 51-100$
$\square 26-50$
ㅁ $0-25$

Source: compiled by the authors.

About 20 core participants are registered in the St. Petersburg ICT cluster, the largest of which are Intel Russia, Tranzas, PROMT, Technoros, Rubin Research Institute, Speech Technology Centre, etc. The cluster also comprises specialized R\&D and educational organizations such as St. Petersburg State Electrotechnical University 'LETI', Bonch-Bruevich St. Petersburg State University of Telecommunications, and St. Petersburg National Research University of Information Technologies, Mechanics and Optics.

The ICT sector demonstrates more uniform conditions for clustering across various Russian regions than other industries (Figure 2).

\section{Table 3. Clustering potential of the ICT industry}

\begin{tabular}{|c|c|c|c|c|c|c|c|c|c|}
\hline Region & $\begin{array}{l}\text { Num- } \\
\text { ber of } \\
\text { com- } \\
\text { panies }\end{array}$ & $\begin{array}{c}\text { Number } \\
\text { of em- } \\
\text { ployees }\end{array}$ & $\begin{array}{c}\text { Cluster } \\
\text { diversifi- } \\
\text { cation by } \\
\text { number } \\
\text { of em- } \\
\text { ployees }\end{array}$ & $\begin{array}{c}\text { Com- } \\
\text { panies' } \\
\text { revenues } \\
\text { (million } \\
\text { roubles) }\end{array}$ & $\begin{array}{l}\text { Cluster } \\
\text { diversifi- } \\
\text { cation by } \\
\text { revenue }\end{array}$ & $\begin{array}{l}\text { Number of } \\
\text { companies } \\
\text { sub-index }\end{array}$ & $\begin{array}{c}\text { Employ- } \\
\text { ment } \\
\text { Cluster- } \\
\text { ing sub- } \\
\text { index }\end{array}$ & $\begin{array}{l}\text { Revenue } \\
\text { Clustering } \\
\text { sub-index }\end{array}$ & $\begin{array}{c}\text { Integral } \\
\text { Clustering } \\
\text { Potential } \\
\text { index }\end{array}$ \\
\hline \multicolumn{10}{|c|}{ Regions with pilot ITCs } \\
\hline St. Petersburg & 9041 & 28541 & 1.00 & 2759 & 1.00 & 0.65 & 0.32 & 0.17 & 0.38 \\
\hline Tomsk Region & 968 & 2697 & 1.00 & 108 & 1.00 & 0.45 & 0.20 & 0.05 & 0.23 \\
\hline $\begin{array}{l}\text { Moscow Region(PhysTech } \\
\text { XXI) }\end{array}$ & 5550 & 10071 & 1.00 & 353 & 1.00 & 0.50 & 0.11 & 0.03 & 0.21 \\
\hline Novosibirsk Region & 2733 & 6381 & 1.00 & 449 & 1.00 & 0.38 & 0.15 & 0.08 & 0.21 \\
\hline $\begin{array}{l}\text { Nizhny Novgorod Region } \\
\text { (Sarov) }\end{array}$ & 2082 & 4755 & 1.00 & 384 & 1.00 & 0.35 & 0.14 & 0.06 & 0.18 \\
\hline \multicolumn{10}{|c|}{ Regions with clustering potential } \\
\hline City of Moscow & 27063 & 152997 & 0.99 & 15831 & 0.99 & 1 & 0.85 & 0.56 & 0.80 \\
\hline Yaroslavl Region & 963 & 9024 & 1.00 & 102 & 1.00 & 0.38 & 0.53 & 0.05 & 0.32 \\
\hline Amur Region & 329 & 1894 & 0.56 & 450 & 0.48 & 0.26 & 0.17 & 0.25 & 0.23 \\
\hline Republic of Tatarstan & 2533 & 7532 & 1.00 & 599 & 1.00 & 0.38 & 0.20 & 0.08 & 0.22 \\
\hline Rostov Region & 2772 & 4349 & 1.00 & 168 & 1.00 & 0.49 & 0.12 & 0.03 & 0.21 \\
\hline Sverdlovsk Region & 3697 & 6055 & 1.00 & 501 & 1.00 & 0.44 & 0.11 & 0.06 & 0.21 \\
\hline
\end{tabular}


Regions with a high potential for developing ICT clusters include the city of Moscow (27,000 companies), Rostov and Sverdlovsk regions, and the Republic of Tatarstan with its significant number of companies and high clustering potential.

\section{Aerospace technologies}

Five ITCs have been created in this sector with public support (Table 4).

Regions where aerospace ITCs are located serve as home bases for industry leaders such as Kuznetsov Co. (Samara), a key aerospace propulsion engineering enterprise; Proton-M (Perm), a manufacturer of liquidfuel rocket engines; Aviakor (Samara), a major player in the passenger aircraft construction, repair, and maintenance market; AeroComposite-Ulyanovsk (Ulyanovsk), a manufacturer of aircraft construction elements, etc. The Gagarin Komsomolsk-on-Amur Aviation Plant, a manufacturer of the Russian medium-haul airliner Sukhoi Superjet 100, is located in Khabarovsk region. The town of Zheleznogorsk (Krasnoyarsk region) is home to the Academician Reshetnikov Information Satellite Systems Company (ISS Co.), the largest Russian satellite manufacturer.

The Samara Aerospace ITC brings together 14 core residents including Kuznetsov Co., Aviakor Aviation Plant, the Progress State Research and Production Rocket and Space Centre, Aerodrome Equipment Factory Co., Ekran Research Institute, and others. Much significant research is conducted at the Gagarin Samara State Technological University and the Samara State Aerospace University named after the Academician Korolev.

Some of the regions which have received government support do not have a sufficient number of small and medium companies to create fully-fledged clusters. This primarily concerns Khabarovsk and Krasnoyarsk regions. At the same time, the above-mentioned pilot ITCs cover multiple industrial sectors: the former includes shipbuilding companies, while the latter includes nuclear energy enterprises.

The cities of Moscow and St. Petersburg, as well as Moscow and Nizhny Novgorod regions also have potential for successfully creating aerospace clusters: more than 100 aerospace enterprises operate in each of them (797 in the city of Moscow), plus major R\&D and educational organizations (Figure 3).

\begin{tabular}{|c|c|c|c|c|c|c|c|c|c|}
\hline Region & $\begin{array}{c}\text { Num- } \\
\text { ber of } \\
\text { com- } \\
\text { panies }\end{array}$ & $\begin{array}{c}\text { Number } \\
\text { of em- } \\
\text { ployees }\end{array}$ & $\begin{array}{l}\text { Cluster } \\
\text { diversifi- } \\
\text { cation by } \\
\text { number of } \\
\text { employees }\end{array}$ & $\begin{array}{c}\text { Com- } \\
\text { panies' } \\
\text { rev- } \\
\text { enues } \\
\text { (million } \\
\text { roubles) }\end{array}$ & $\begin{array}{l}\text { Cluster } \\
\text { diversifi- } \\
\text { cation by } \\
\text { revenue }\end{array}$ & $\begin{array}{l}\text { Number of } \\
\text { companies } \\
\text { sub-index }\end{array}$ & $\begin{array}{c}\text { Employ- } \\
\text { ment } \\
\text { Cluster- } \\
\text { ing sub- } \\
\text { index }\end{array}$ & $\begin{array}{l}\text { Revenue } \\
\text { Clustering } \\
\text { sub-index }\end{array}$ & $\begin{array}{c}\text { Integral } \\
\text { Clustering } \\
\text { Potential } \\
\text { index }\end{array}$ \\
\hline \multicolumn{10}{|c|}{ Aircraft and spacecraft manufacturing clusters (OKVED codes $353,35304,35305,35309$ ) } \\
\hline \multicolumn{10}{|c|}{ Regions with pilot ITCs } \\
\hline Samara Region & 70 & 26155 & 0.77 & 24620 & 0.82 & 0.22 & 0.58 & 0.17 & 0.33 \\
\hline Perm Region & 14 & 9326 & 0.71 & 24865 & 0.76 & 0.01 & 0.21 & 0.17 & 0.13 \\
\hline $\begin{array}{l}\text { Ulyanovsk Region } \\
\text { (Ulyanovsk-Avia) }\end{array}$ & 31 & 150 & 0.75 & 685 & 0.75 & 0.13 & 0.01 & 0.01 & 0.05 \\
\hline Khabarovsk Region & 13 & 0 & 1.00 & 0 & 1.00 & 0.02 & 0.00 & 0.00 & 0.01 \\
\hline Krasnoyarsk Region & 15 & 0 & 1.00 & 0 & 1.00 & 0.01 & 0.00 & 0.00 & 0.00 \\
\hline \multicolumn{10}{|c|}{ Regions with clustering potential } \\
\hline City of Moscow & 797 & 15161 & 0.87 & 66547 & 0.72 & 0.87 & 0.27 & 0.36 & 0.50 \\
\hline Moscow Region & 272 & 9952 & 0.88 & 20649 & 0.88 & 0.67 & 0.20 & 0.14 & 0.34 \\
\hline St. Petersburg & 107 & 20707 & 0.89 & 49334 & 0.90 & 0.21 & 0.42 & 0.35 & 0.32 \\
\hline Nizhny Novgorod Region & 19 & 18745 & 0.82 & 21114 & 0.82 & 0.02 & 0.47 & 0.15 & 0.21 \\
\hline Republic of Tatarstan & 87 & 7812 & 0.24 & 44315 & 0.09 & 0.31 & 0.06 & 0.03 & 0.13 \\
\hline Rostov Region & 42 & 15397 & 0.49 & 33552 & 0.12 & 0.08 & 0.23 & 0.03 & 0.11 \\
\hline \multicolumn{10}{|c|}{ Propulsion engineering (power plants) clusters (OKVED code 35301) } \\
\hline \multicolumn{10}{|c|}{ Regions with pilot ITCs } \\
\hline Perm Region & 7 & 5349 & 1.00 & 14085 & 0.48 & 0.02 & 0.24 & 0.15 & 0.14 \\
\hline \multicolumn{10}{|c|}{ Regions with clustering potential } \\
\hline City of Moscow & 44 & 6791 & 0.44 & 7271 & 0.40 & 0.27 & 0.08 & 0.04 & 0.13 \\
\hline Yaroslavl Region & 3 & 13387 & 0.18 & 18932 & 0.12 & 0.01 & 0.15 & 0.09 & 0.08 \\
\hline Omsk Region & 7 & 1341 & 1.00 & 3035 & 0.49 & 0.03 & 0.08 & 0.06 & 0.06 \\
\hline
\end{tabular}




\section{Figure 3. Integral Clustering Potential Index of the Russian aerospace industry (2013 data)}

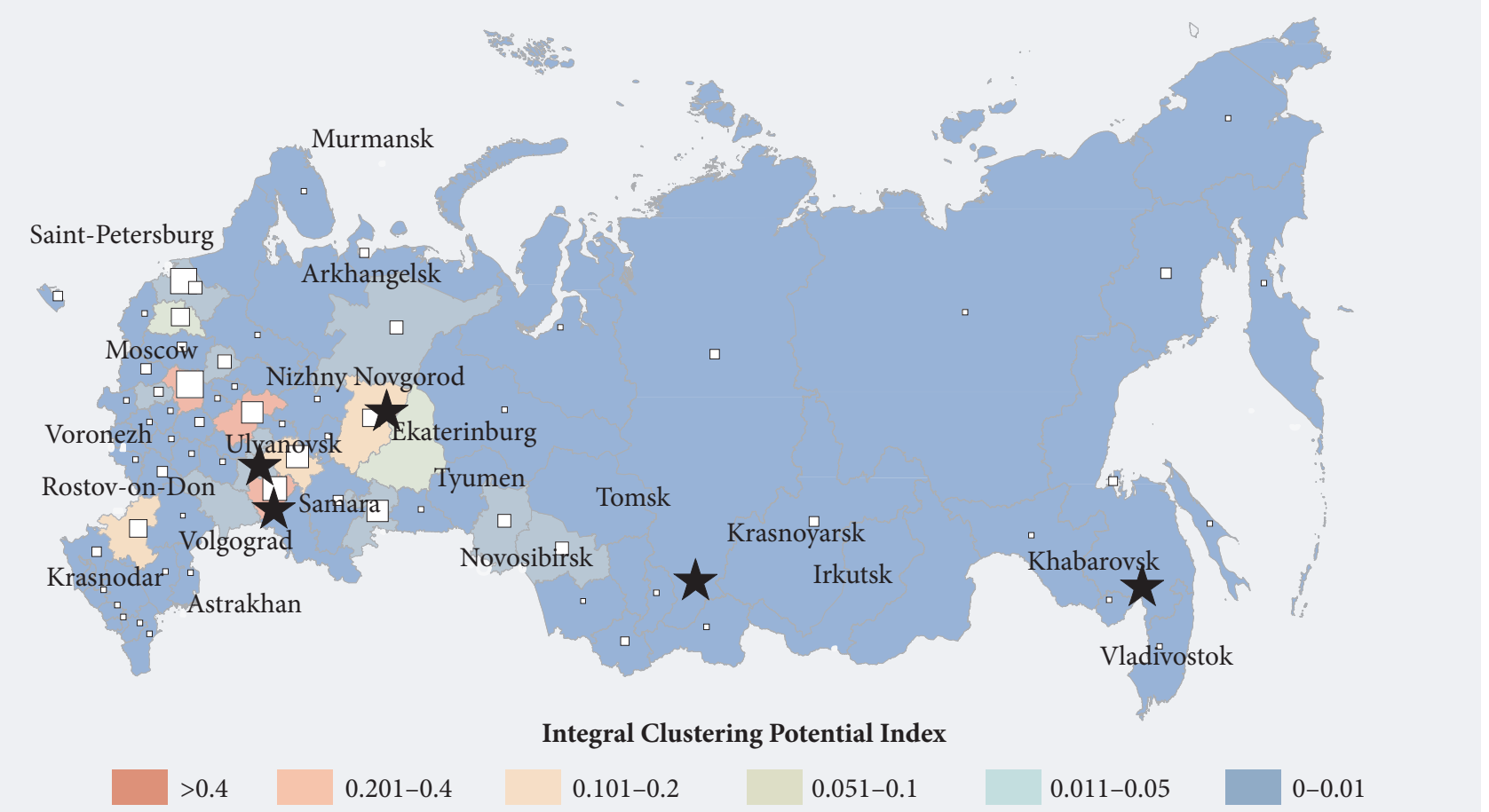

Number of companies in the region specializing in the industry
$>500$
$\square$ 201-500
$\square 101-200$
$\square 51-100$
$\square 26-50$
$\square 0-25$

Source: compiled by the authors.

\section{Petrochemical industry}

Three pilot ITCs are currently being supported in the petrochemical industry: in the Republics of Bashkortostan and Tatarstan, and in Nizhny Novgorod region (Table 5). The deconcentration index in the above-mentioned regions is about 0.5. All three regions have many petrochemical companies: Bashkortostan and Tatarstan have about 1,000, and Nizhny Novgorod region has about 765. The largest companies are: Lukoil-Nizhegorodneftorgsyntez (in the city of Kstovo and Kstovo District in Nizhny Novgorod region), GAZPROM Neftekhim Salavat (in the city of Salavat in the Republic of Bashkortostan), TAIF-NK and TANEKO (in the city of Nizhnekamsk in the Republic of Tatarstan).

Core participants of the Kama Production ITC currently include 30 organizations, including: Tatneftekhiminvest Holding, Tatneft-Neftekhim, TANEKO, Nizhnekamskneftekhim, Tatneft Petrochemical Complex. The cluster comprises a significant number of R\&D centres including Kazan National Research Technological University, the Tupolev Kazan National Research Technological University, Kazan (Privolzhsky) Federal University, Kazan Chemical Research Institute, Kama State Engineering Economic Academy in Naberezhnye Chelny, and Kazan State Energy University.

Our calculations suggest that petrochemical enterprises in the city of Moscow and Moscow region have a high clustering potential (Figure 4), although certain specifically Russian aspects such as legal entities being registered at their headquarters' location (i.e. in many cases, in the national capital) must be taken into account. Thus, statistics do not always reflect the actual location of production facilities. All major petrochemical companies operating primarily in Western Siberia are registered in the Moscow capital region, which significantly skews the geography of the Russian petrochemical industry.

A trend towards clustering was also displayed by petrochemical companies in Yaroslavl, Omsk, and Samara regions. 850 firms specializing in this industry operate in the latter region, with an average diversification level exceeding 0.85 .

\section{Instruments and electronics}

This industry's diversification index is close to 1 , not just in the regions where relevant clusters already receive government support but in several other areas as well. This indicator value suggests a high potential for both cooperation and competition between cluster participants (Table 6).

The official list of ITCs features just one cluster specializing in instrumentation engineering and located in Saransk (Republic of Mordovia). This cluster's production potential (132 companies) is much lower than the city of Moscow's, the leader region with 


\section{Figure 4. Integral Clustering Potential Index of the Russian petrochemical industry (2013 data)}

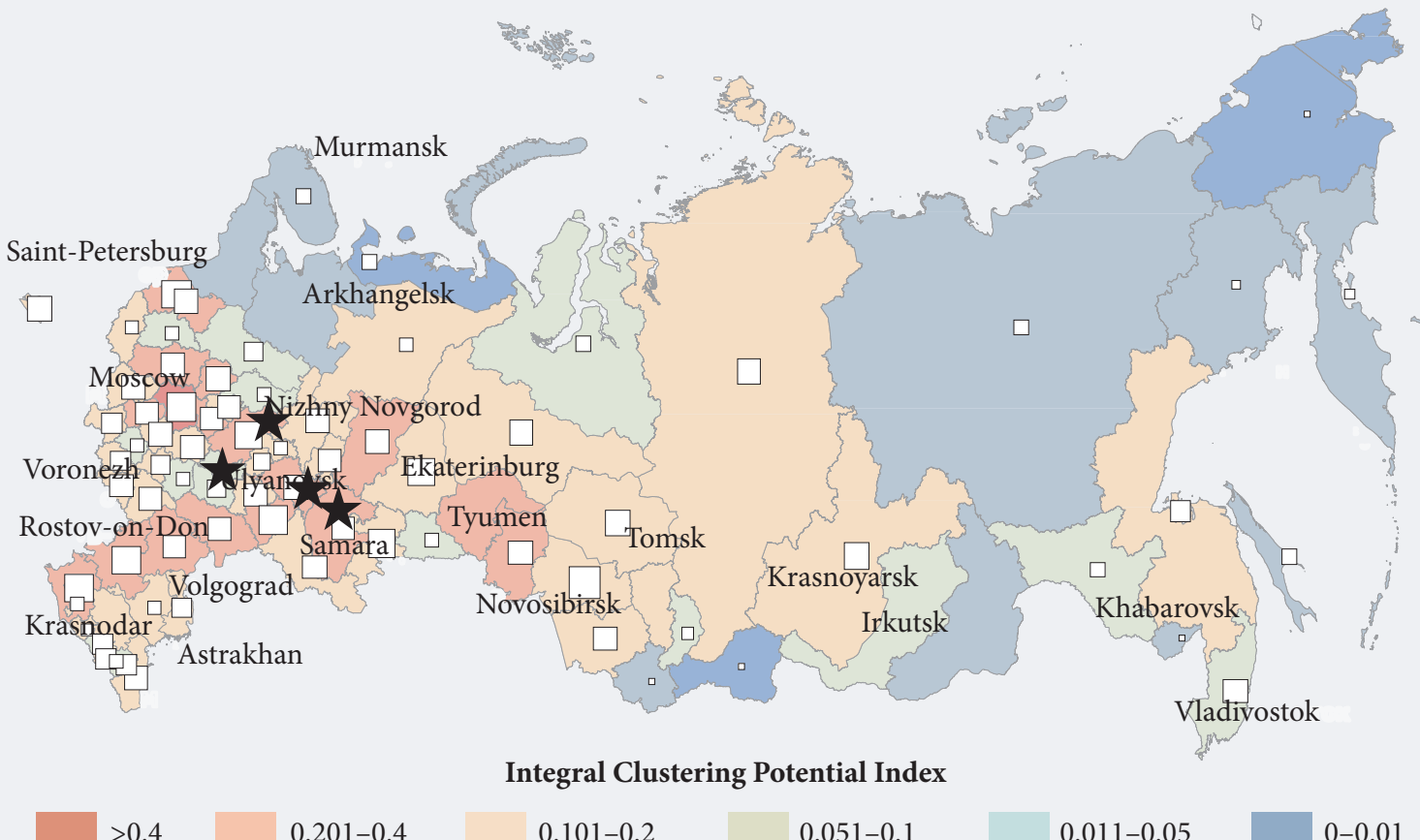

Number of companies in the region specializing in the industry

$\square>500 \quad \square$ 201-500 $\square$ 101-200 $\square$ 51-100 $\square$ 26-50 $\square$ 0-25

Source: compiled by the authors.

about 5,000 companies. The Mordovian instruments cluster mainly specializes in production of lighting equipment and comprises only about ten core residents, including Electrovypriamitel, Kadoshkinsky Electrical Engineering Plant, Saransk Precision Instruments Plant, and the Lodygin Lighting Sources Research Institute, etc.

We found significant clustering potential for instrument-making companies in the city of Moscow (approx. 4,960 enterprises), St. Petersburg (2,720 enterprises), and in Moscow Region (about 1,300 enterprises).

\begin{tabular}{|c|c|c|c|c|c|c|c|c|c|}
\hline Region & $\begin{array}{l}\text { Num- } \\
\text { ber of } \\
\text { com- } \\
\text { panies }\end{array}$ & $\begin{array}{c}\text { Number } \\
\text { of em- } \\
\text { ployees }\end{array}$ & $\begin{array}{c}\text { Cluster } \\
\text { diversifi- } \\
\text { cation by } \\
\text { number } \\
\text { of em- } \\
\text { ployees }\end{array}$ & $\begin{array}{c}\text { Com- } \\
\text { panies' } \\
\text { revenues } \\
\text { (million } \\
\text { roubles) }\end{array}$ & $\begin{array}{l}\text { Cluster } \\
\text { diversifi- } \\
\text { cation by } \\
\text { revenue }\end{array}$ & $\begin{array}{c}\text { Number } \\
\text { of compa- } \\
\text { nies sub- } \\
\text { index }\end{array}$ & $\begin{array}{c}\text { Employ- } \\
\text { ment } \\
\text { Cluster- } \\
\text { ing sub- } \\
\text { index }\end{array}$ & $\begin{array}{l}\text { Revenue } \\
\text { Cluster- } \\
\text { ing sub- } \\
\text { index }\end{array}$ & $\begin{array}{l}\text { Integral } \\
\text { Clustering } \\
\text { Potential } \\
\text { index }\end{array}$ \\
\hline \multicolumn{10}{|c|}{ Regions with pilot ITCs } \\
\hline Republic of Tatarstan & 983 & 21473 & 0.91 & 153348 & 0.29 & 0.47 & 0.59 & 0.10 & 0.38 \\
\hline Republic of Bashkortostan & 1083 & 15752 & 0.79 & 172476 & 0.06 & 0.63 & 0.41 & 0.02 & 0.35 \\
\hline $\begin{array}{l}\text { Nizhny Novgorod Region } \\
\text { (Nizhny Novgorod, Kstovo) }\end{array}$ & 765 & 14892 & 0.95 & 355235 & 0.01 & 0.40 & 0.45 & 0.01 & 0.29 \\
\hline \multicolumn{10}{|c|}{ Regions with clustering potential } \\
\hline City of Moscow & 4044 & 39582 & 0.99 & 112842 & 0.64 & 0.69 & 0.56 & 0.10 & 0.45 \\
\hline Moscow Region & 1889 & 34305 & 0.99 & 7346 & 0.81 & 0.58 & 0.64 & 0.01 & 0.41 \\
\hline Samara Region & 847 & 17353 & 0.91 & 58081 & 0.76 & 0.44 & 0.47 & 0.10 & 0.34 \\
\hline Yaroslavl Region & 299 & 12169 & 0.88 & 28065 & 0.39 & 0.33 & 0.58 & 0.05 & 0.32 \\
\hline Omsk Region & 376 & 11493 & 0.87 & 40425 & 0.37 & 0.35 & 0.53 & 0.07 & 0.32 \\
\hline St. Petersburg & 1456 & 21675 & 0.98 & 61084 & 0.61 & 0.38 & 0.39 & 0.06 & 0.28 \\
\hline Krasnodar Region & 1021 & 10378 & 0.97 & 142443 & 0.68 & 0.41 & 0.23 & 0.19 & 0.27 \\
\hline Volgograd Region & 408 & 13045 & 0.76 & 249898 & 0.04 & 0.32 & 0.45 & 0.04 & 0.27 \\
\hline Saratov Region & 407 & 9830 & 0.76 & 13063 & 0.07 & 0.38 & 0.40 & 0.00 & 0.26 \\
\hline Perm Region & 470 & 13641 & 0.82 & 293968 & 0.11 & 0.31 & 0.38 & 0.08 & 0.26 \\
\hline Leningrad Region & 216 & 7800 & 0.92 & 62208 & 0.43 & 0.24 & 0.38 & 0.10 & 0.24 \\
\hline
\end{tabular}




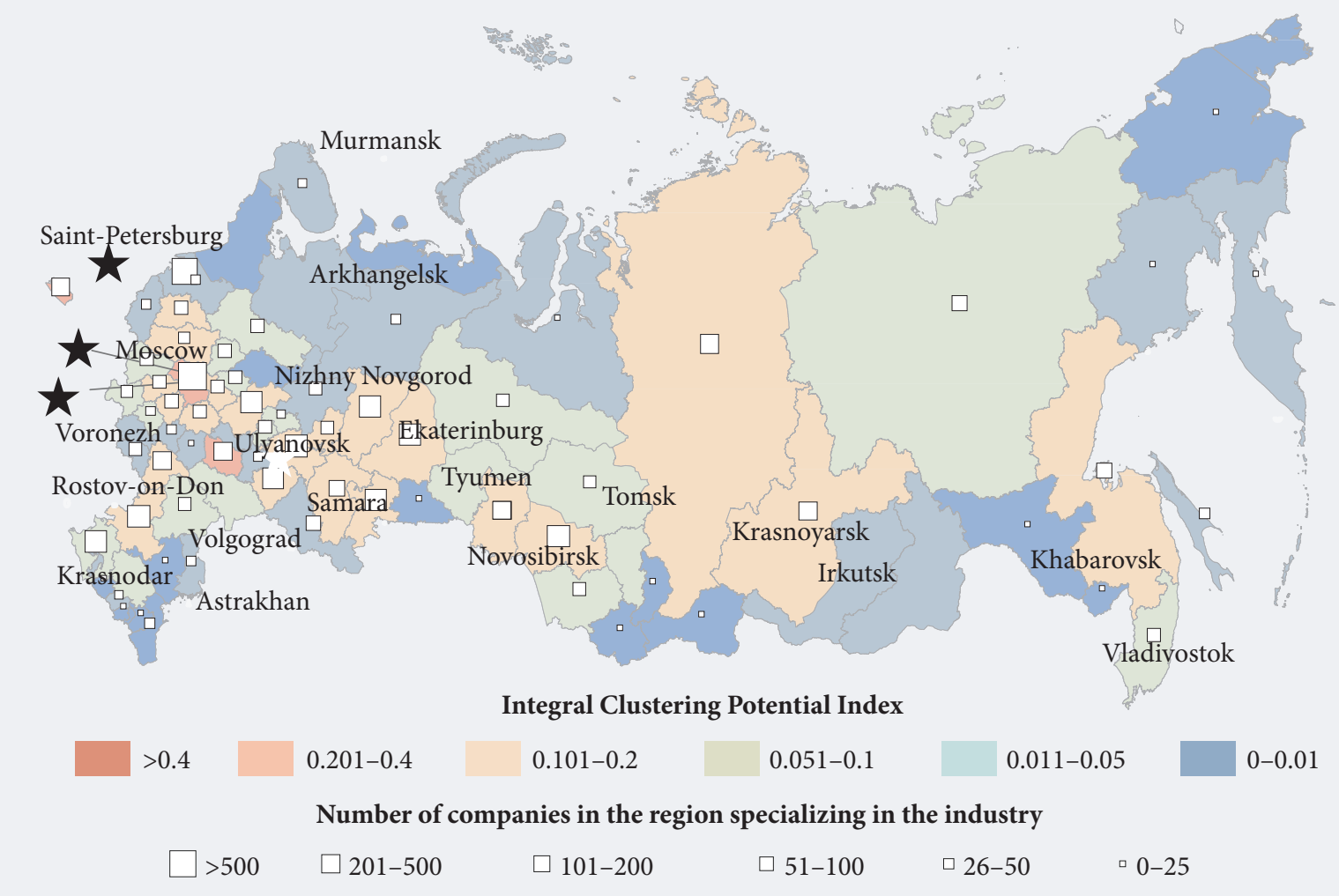

Source: compiled by the authors.

In the electronics industry, we found a complete match between the publicly supported clusters and their home region potential (Figure 5). The two biggest clusters are located in the city of Moscow (Zelenograd) and St. Petersburg, with approx. 4,400 and 1,200 companies respectively. The most significant members of the Zelenograd cluster include: the Molecular Electronics Research Institute and Micron Plant, Angstrem Group, ELVIS Research and Production Centre, Institute of Microelectronics Design of the Russian Academy of Sciences (RAS), and the Zelenograd Nanotechnology Centre.

According to our estimates, Kaliningrad, Kaluga, Penza, Ryazan, and Moscow regions also have significant clustering potential in the instrumentation engineering and electronics industries.

\section{Shipbuilding}

Two ITCs have been established in the shipbuilding industry in Archangel region (the companies are located in Severodvinsk and Archangel), and Khabarovsk region (the cities of Khabarovsk and Komsomolsk-on-Amur). There are about 120 and over 50 shipbuilding companies in Archangel and Khabarovsk regions respectively.

Our calculations show that the clustering potential of the selected regions is lower than in St. Petersburg, Primorsky, Astrakhan, and Murmansk regions. This opens up opportunities for establishing alternative shipbuilding clusters, provided they can successfully complete the initial organizational stage.

In Archangel region, the low clustering potential is primarily due to the high monopolization of the shipbuilding industry due to the activities of the undisputed industry leaders such as the biggest in Russia Sevmash Co. and Zvezdochka Ship Repair Centre (the latter generates more than $90 \%$ of all shipbuilding industry's revenues in the region). R\&D organizations also play a major role, specifically the Onega Design and Research Bureau, Shipbuilding and Marine Arctic Machinery Research Institute of the Lomonosov Northern (Arctic) Federal University, and the North-Western Branch of the Safe Nuclear Energy Institute of the RAS.

Khabarovsk region has even less favourable conditions for creating a shipbuilding cluster than Archangel region. For example, the number of relevant companies here does not exceed 100, while the monopolization level is higher. The Amur Shipbuilding Factory Public Company is the only large shipyard, generating practically all revenues and employing all regional shipbuilding workers. 


\section{Figure 6. Integral Clustering Potential Index of the Russian shipbuilding industry (2013 data)}

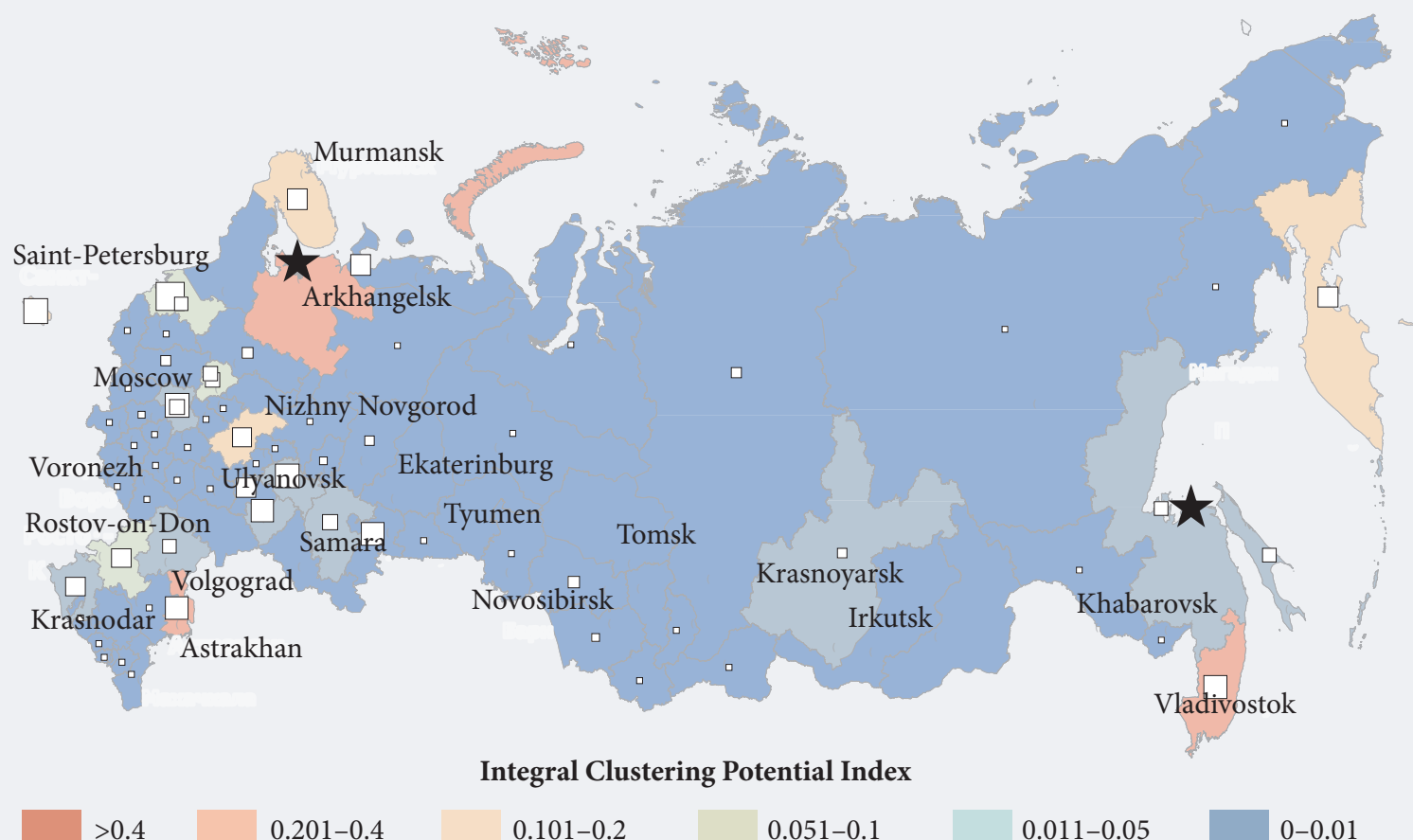

Number of companies in the region specializing in the industry
$\square>500$
$\square 201-500$
$\square 101-200$
$\square 51-100$
$\square$ 26-50
$\square 0-25$

Source: compiled by the authors.

\section{Table 6. Clustering potential of the instrumentation and electronics industries}

\begin{tabular}{|l|c|c|c|c|c|c|c|c|c|}
\hline Region & $\begin{array}{c}\text { Num- } \\
\text { ber of } \\
\text { compa- } \\
\text { nies }\end{array}$ & $\begin{array}{c}\text { Num- } \\
\text { ber of } \\
\text { em- } \\
\text { ployees }\end{array}$ & $\begin{array}{c}\text { Cluster } \\
\text { diversifi- } \\
\text { cation by } \\
\text { number of } \\
\text { employees }\end{array}$ & $\begin{array}{c}\text { Com- } \\
\text { panies' } \\
\text { revenues } \\
\text { (million } \\
\text { roubles) }\end{array}$ & $\begin{array}{c}\text { Cluster } \\
\text { diversif- } \\
\text { cation by } \\
\text { revenue }\end{array}$ & $\begin{array}{c}\text { Number } \\
\text { of compa- } \\
\text { nies sub- } \\
\text { index }\end{array}$ & $\begin{array}{c}\text { Employ- } \\
\text { ment } \\
\text { Cluster- } \\
\text { ing sub- } \\
\text { index }\end{array}$ & $\begin{array}{c}\text { Revenue } \\
\text { Cluster- } \\
\text { ing sub- } \\
\text { index }\end{array}$ & $\begin{array}{c}\text { Integral } \\
\text { Clustering } \\
\text { Potential } \\
\text { index }\end{array}$ \\
\hline
\end{tabular}

\begin{tabular}{|l|r|r|r|r|r|r|r|r|r|r|r|}
\hline \multicolumn{7}{|c|}{ Electrical machinery production (instrumentation) clusters (OKVED code 31) } \\
\hline \multicolumn{8}{|c|}{ Regions with pilot ITCs } \\
\hline Republic of Mordovia & 132 & 7362 & 0.81 & 13169 & 0.88 & 0.33 & 0.47 & 0.32 & 0.37 \\
\hline \multicolumn{8}{|c|}{ Regions with clustering potential } \\
\hline City of Moscow (Zelenograd) & 4962 & 47534 & 0.99 & 120685 & 0.99 & 0.72 & 0.54 & 0.50 & 0.59 \\
\hline St. Petersburg & 2720 & 31753 & 0.99 & 103719 & 0.97 & 0.66 & 0.44 & 0.47 & 0.52 \\
\hline Chuvash Republic & 324 & 8773 & 1.00 & 20340 & 1.00 & 0.53 & 0.45 & 0.44 & 0.48 \\
\hline Pskov Region & 145 & 7389 & 0.87 & 17221 & 0.88 & 0.36 & 0.45 & 0.50 & 0.44 \\
\hline Vladimir Region & 290 & 12340 & 0.91 & 24061 & 0.80 & 0.34 & 0.47 & 0.30 & 0.37 \\
\hline Sverdlovsk Region & 1319 & 15665 & 0.97 & 34567 & 0.94 & 0.50 & 0.27 & 0.19 & 0.32 \\
\hline Moscow Region & 1322 & 24801 & 0.98 & 51490 & 0.97 & 0.37 & 0.35 & 0.25 & 0.32 \\
\hline Samara Region & 786 & 18883 & 0.77 & 44322 & 0.76 & 0.39 & 0.30 & 0.23 & 0.31 \\
\hline
\end{tabular}

Electronics clusters (OKVED code 32)

\begin{tabular}{|l|r|r|r|r|r|r|r|r|r|r|}
\hline \multicolumn{10}{|c|}{ Regions with pilot ITCs } \\
\hline Moscow (Zelenograd) & 4383 & 37845 & 0.98 & 85191 & 0.96 & 1.00 & 0.56 & 0.54 & 0.70 \\
\hline St. Petersburg & 1277 & 17806 & 0.96 & 22121 & 0.85 & 0.56 & 0.34 & 0.22 & 0.37 \\
\hline \multicolumn{8}{|c|}{ Regions with clustering potential } \\
\hline Penza Region & 106 & 1737 & 0.66 & 2873 & 0.51 & 0.33 & 0.09 & 0.26 & 0.23 \\
\hline Kaliningrad Region & 179 & 2274 & 0.89 & 3146 & 0.29 & 0.38 & 0.16 & 0.08 & 0.21 \\
\hline Kaluga Region & 85 & 5324 & 0.78 & 2302 & 0.40 & 0.22 & 0.31 & 0.08 & 0.20 \\
\hline Riazan Region & 93 & 4770 & 0.61 & 461 & 0.73 & 0.24 & 0.22 & 0.04 & 0.17 \\
\hline Moscow Region & 681 & 2941 & 0.92 & 3712 & 0.84 & 0.36 & 0.05 & 0.05 & 0.15 \\
\hline Source: compiled by the authors. & \multicolumn{10}{|c|}{} \\
\hline
\end{tabular}




\section{Figure 7. Integral Clustering Potential Index of the Russian automobile industry (2013 data)}

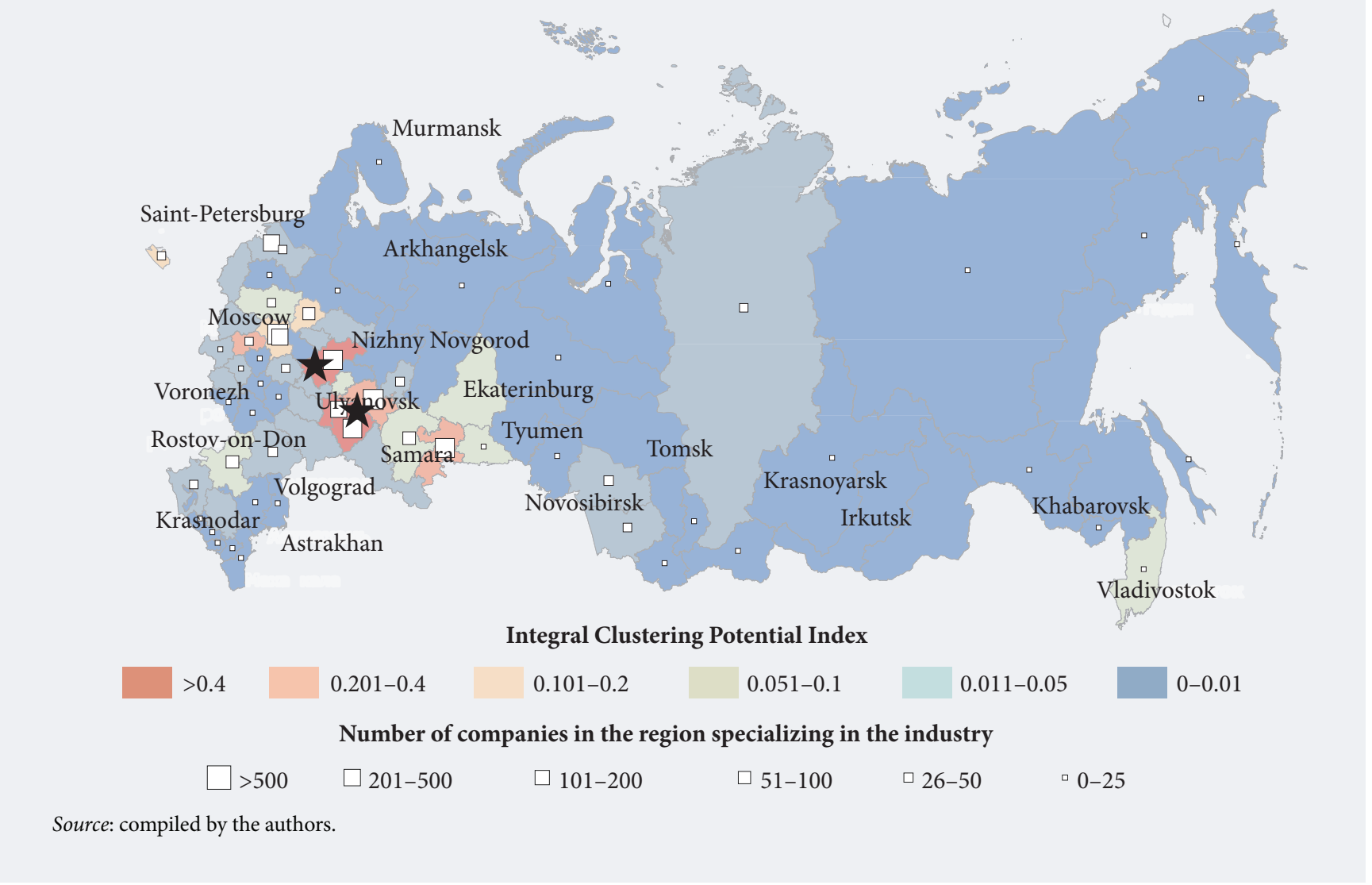

As to possible alternative Russian regions (Figure 6), St. Petersburg has a much higher shipbuilding clustering potential: its deconcentration index reaches approximately 0.7 , and the number of relevant companies exceeds 600 . Leading positions are shared by the four biggest companies of which two are particularly powerful, playing a major role not just in the regional but also in the national economy: the Admiralty Shipyard, the Northern Shipyard shipbuilding factory, the Sredne-Nevsky shipbuilding factory, and the Almaz Shipbuilding Company.

Other Russian regions with a high clustering potential worthy of note include the regions of Primorsky (420 companies, diversification index 0.65), Astrakhan (247 companies, diversification index 0.77), and Nizhny Novgorod (178 companies, diversification index 0.64).

\section{Automobile industry}

The Russian automobile industry was booming in the second half of the 2000s, fuelled by investments by major global corporations including Volkswagen, Toyota, Nissan, Ford, Volvo, Hyundai, etc. Clusters comprising significant numbers of small and medium companies (mainly supplies of parts and components) emerged around large plants, built during the Soviet period and subsequently.

Automobile clusters were established in two regions: Nizhny Novgorod region and the Republic of Tatarstan (Table 8). They comprise major Russian automobile factories such as GAZ Group (Nizhny Novgorod Region) KAMAZ (Naberezhnye Chelny, the Republic of Tatarstan), and Ford Sollers Elabuga (Elabuga, the Republic of Tatarstan). The above-mentioned regions also serve as home bases for other major companies such as Pavlovo Bus Factory and Zavolzhsky Motor Factory (Nizhny Novgorod Region), and Elabuga Automobile Factory (Republic of Tatarstan).

Prospective regions in terms of developing automobile clusters also include Samara region (421 firms, of which the largest is AutoVAZ), Ulyanovsk region (153 companies, the largest being Ulyanovsk Automobile Factory), and the city of Moscow (431 companies, the biggest are the Likhachev Plant and Renault Russia (until 2014, 'Autoframos').

The geographical distribution of automotive companies also prompts one to note St. Petersburg (with 188 firms), which has assembly plants of Toyota, Nissan, General Motors, Hyundai, Scania (buses) and Magna (a car parts factory). Moreover, Kaluga and Kaliningrad regions have car assembly facilities. 


\section{Table 7. Clustering potential of the shipbuilding industry}

\begin{tabular}{|l|c|c|c|c|c|c|c|c|c|}
\hline Region & $\begin{array}{c}\text { Num- } \\
\text { ber of } \\
\text { compa- } \\
\text { nies }\end{array}$ & $\begin{array}{c}\text { Num- } \\
\text { ber of } \\
\text { em- } \\
\text { ployees }\end{array}$ & $\begin{array}{c}\text { Cluster } \\
\text { diversifi- } \\
\text { cation by } \\
\text { number of } \\
\text { employees }\end{array}$ & $\begin{array}{c}\text { Com- } \\
\text { panies' } \\
\text { revenues } \\
\text { (million } \\
\text { roubles) }\end{array}$ & $\begin{array}{c}\text { Cluster } \\
\text { diversifi- } \\
\text { cation by } \\
\text { revenue }\end{array}$ & $\begin{array}{c}\text { Number } \\
\text { of compa- } \\
\text { nies sub- } \\
\text { index }\end{array}$ & $\begin{array}{c}\text { Employ- } \\
\text { ment } \\
\text { Cluster- } \\
\text { ing sub- } \\
\text { index }\end{array}$ & $\begin{array}{c}\text { Revenue } \\
\text { Cluster- } \\
\text { ing sub- } \\
\text { index }\end{array}$ & $\begin{array}{c}\text { Integral } \\
\text { Clustering } \\
\text { Potential } \\
\text { index }\end{array}$ \\
\hline
\end{tabular}

\begin{tabular}{|l|r|r|r|r|r|r|r|r|r|r|r|}
\hline \multicolumn{10}{|c|}{ Regions with pilot ITCs } \\
\hline Archangelsk Region & 119 & 15634 & 0.22 & 31839 & 0.25 & 0.30 & 0.22 & 0.19 & 0.24 \\
\hline Khabarovsk Region & 55 & 3394 & 0.02 & 3890 & 0.04 & 0.06 & 0.004 & 0.002 & 0.02 \\
\hline \multicolumn{10}{|c|}{ Regions with clustering potential } \\
\hline St. Petersburg & 616 & 13690 & 0.71 & 58828 & 0.68 & 0.60 & 0.34 & 0.36 & 0.43 \\
\hline Astrakhan Region & 247 & 1616 & 0.79 & 2011 & 0.76 & 0.70 & 0.12 & 0.05 & 0.29 \\
\hline Primorsky Region & 420 & 1175 & 0.73 & 5353 & 0.57 & 0.66 & 0.04 & 0.04 & 0.25 \\
\hline Murmansk Region & 190 & 99 & 0.44 & 260 & 0.50 & 0.54 & 0.00 & 0.00 & 0.18 \\
\hline Kamchatka Region & 107 & 28 & 0.63 & 29 & 0.76 & 0.51 & 0.00 & 0.00 & 0.17 \\
\hline Kaliningrad Region & 218 & 3587 & 0.16 & 12716 & 0.08 & 0.39 & 0.04 & 0.02 & 0.15 \\
\hline Nizhny Novgorod Region & 178 & 5255 & 0.56 & 6894 & 0.72 & 0.23 & 0.12 & 0.05 & 0.13 \\
\hline Source: compiled by the authors. & & &
\end{tabular}

Source: compiled by the authors.

\section{Other industries}

Coal is not traditionally considered a high-tech industry. However, related industries, primarily coal chemistry and waste recycling, do have significant innovation potential. A pilot ITC in this sector was created in Kemerovo region which has the best conditions for developing such clusters: 715 companies specializing in the coal industry operate in this region, employing about 67,000 people. Along with major firms such as SUEK and Belovskaya Mine, the cluster participants include R\&D and educational organizations, namely Kemerovo Research Centre of the Siberian Branch of the RAS, Gorbachev Kuzbass State Technological University, and the Siberian State Industrial University. Structurally closer to a classic territorial production complex, this cluster is designed not so much to promote the development of the coal industry in Kemerovo region as to provide systemic support to new industries such as coal chemistry, waste recycling, and environmental protection. Potential competition to Kemerovo region could come from the Republic of Khakassia, Krasnoyarsk, Rostov, and Sakhalin regions.

The methodology that we have presented in this paper for estimating the match between regions with pilot ITCs and the actual conditions affecting cluster development in Russia is more applicable in the civilian sectors of the Russian economy. Applying this methodology to monitor 'closed' strategic industries is not possible due to the lack of publicly available relevant data. Some of these industries, however, are represented in the pilot ITCs, including new materials (the titanium cluster in Sverdlovsk region),

Table 8 . Clustering potential of the automobile industry

\begin{tabular}{|c|c|c|c|c|c|c|c|c|c|}
\hline Region & $\begin{array}{l}\text { Num- } \\
\text { ber of } \\
\text { compa- } \\
\text { nies }\end{array}$ & $\begin{array}{c}\text { Number } \\
\text { of em- } \\
\text { ployees }\end{array}$ & $\begin{array}{c}\text { Cluster } \\
\text { diversifi- } \\
\text { cation by } \\
\text { number of } \\
\text { employees }\end{array}$ & $\begin{array}{c}\text { Com- } \\
\text { panies' } \\
\text { revenues } \\
\text { (million } \\
\text { roubles) }\end{array}$ & $\begin{array}{l}\text { Cluster } \\
\text { diversifi- } \\
\text { cation by } \\
\text { revenue }\end{array}$ & $\begin{array}{l}\text { Number } \\
\text { of compa- } \\
\text { nies sub- } \\
\text { index }\end{array}$ & $\begin{array}{c}\text { Employ- } \\
\text { ment } \\
\text { Cluster- } \\
\text { ing sub- } \\
\text { index }\end{array}$ & $\begin{array}{l}\text { Revenue } \\
\text { Cluster- } \\
\text { ing sub- } \\
\text { index }\end{array}$ & $\begin{array}{c}\text { Integral } \\
\text { Clustering } \\
\text { Potential } \\
\text { index }\end{array}$ \\
\hline \multicolumn{10}{|c|}{ Regions with pilot ITCs } \\
\hline $\begin{array}{l}\text { Nizhny Novgorod Region } \\
\text { (Nizhny Novgorod) }\end{array}$ & 250 & 16350 & 0.95 & 8631 & 0.68 & 0.55 & 0.41 & 0.43 & 0.46 \\
\hline Republic of Tatarstan & 321 & 9788 & 0.93 & 5285 & 0.53 & 0.66 & 0.23 & 0.20 & 0.36 \\
\hline \multicolumn{10}{|c|}{ Regions with clustering potential } \\
\hline Samara Region & 421 & 25085 & 0.95 & 7816 & 0.49 & 0.91 & 0.61 & 0.28 & 0.60 \\
\hline Ulyanovsk Region & 153 & 24423 & 0.83 & 1607 & 0.73 & 0.68 & 0.82 & 0.18 & 0.56 \\
\hline St. Petersburg & 188 & 21984 & 0.92 & 8744 & 0.71 & 0.28 & 0.44 & 0.37 & 0.36 \\
\hline City of Moscow & 431 & 13148 & 0.86 & 5652 & 0.62 & 0.55 & 0.23 & 0.19 & 0.33 \\
\hline Chelyabinsk Region & 229 & 17637 & 0.84 & 1246 & 0.85 & 0.50 & 0.39 & 0.08 & 0.32 \\
\hline Kaluga Region & 42 & 7964 & 0.82 & 9110 & 0.33 & 0.08 & 0.24 & 0.33 & 0.22 \\
\hline Moscow Region & 158 & 6261 & 0.89 & 3689 & 0.49 & 0.26 & 0.12 & 0.11 & 0.16 \\
\hline Kaliningrad Region & 39 & 3139 & 0.63 & 4581 & 0.62 & 0.05 & 0.08 & 0.33 & 0.15 \\
\hline Yaroslavl Region & 51 & 13031 & 0.67 & 742 & 0.49 & 0.10 & 0.29 & 0.04 & 0.14 \\
\hline Republic of Bashkortostan & 72 & 10992 & 0.53 & 476 & 0.61 & 0.12 & 0.15 & 0.02 & 0.10 \\
\hline
\end{tabular}


radiation technologies (the city of Moscow, Moscow, Nizhny Novgorod, and Ulyanovsk regions), and the production of nuclear materials (Moscow, Ulyanovsk, Nizhny Novgorod, and Krasnoyarsk regions).

\section{Types of pilot innovative clusters in Russia}

Measuring the clustering potential of Russian pilot ITCs in high-tech industries has shown that the economic activities considered are not equally suitable for implementing such initiatives. The differences are due to their diverse territorial distribution, the existing market structure, and the shares of small and medium businesses. The industries described above can be notionally divided into three groups, based on their clustering potential (in descending order).

Industries with the highest clustering potential index include pharmaceuticals, production of medical equipment, and biotechnology; ICT; instrumentation engineering (production of electrical machinery), and electronics. The above industries display a high level of innovation activities, are concentrated in regions with the highest innovation potential [Baburin, Zemtsov, 2013], and most of the pilot ITCs specialize in them. Other Russian regions also have significant potential for the emergence of new clusters; this is particularly important in light of the programme for industrial clusters launched by the Russian Ministry of Industry and Trade in 2016.

Recent overall government spending cuts increase the need to more carefully select recipients of public support. The clustering potential of industries can be an important criterion of such selection, together with clusters' characteristics (number of cluster participants, number of companies' employees, amount of investment, export potential, etc.), and cluster participants' specific projects.

Our study covered a limited range of economic activities. Hence, further research should identify more industries that are receptive to cluster policies. At the same time, statistical classifications tend to become obsolete quite quickly and data analysis takes time; in other words, such methodologies are admittedly unsuitable for detecting emerging industries. ${ }^{10}$ That does not imply, however, that the cluster approach is useless. On the contrary, it may potentially prove the best way to provide systemic support to fastgrowing companies (gazelles) when they are expanding, establishing close links with universities and R\&D organizations, and interacting with state-owned companies. Moreover, a cluster approach can help to fine-tune various government policies, in particular to promote exports and technology transfer. The significance of supporting emerging industries suggests that they should be included in the group with the highest clustering potential to implement cluster policy.

Next comes the group of industries that are important to the Russian economy: those with an established territorial structure of production facilities and a high degree of monopolization due to the presence of very big companies. Such sectors include petrochemicals, shipbuilding, coal, aircraft and spacecraft construction, propulsion engineering, and automobiles. Many of these can be classified as Russian hightech industries which define the country's technological image globally. Other industries in this group have matured or are in decline. The probability of gazelle companies emerging in such sectors is lower, while the chances of encountering the 'self-blocking effect' are much higher. Supporting clusters in such industries is hindered by the problem of regional networks who are less interested in promoting innovation and more in preserving the status quo in the economy. Under such circumstances, the government should play a more active role, helping industries to adjust to future markets and restructure their production, in particular by increasing the share of small and medium companies making highquality products. One specific measure that could be introduced is to make it compulsory to link relevant cluster projects with the results of the Russian Long-Term S\&T Foresight or with the National Technology Initiative's roadmaps.

The third group of industries comprises production of new materials (e.g. the titanium cluster in Sverdlovsk region), and nuclear and radiation technologies (we lack reliable data about the latter). These spheres are among the hardest for new companies to enter and freely operate in the market, while the existing players are managed and controlled by the government. This eliminates the potential for this group to be expanded by new private businesses coming in. However, supporting such clusters did bring some results during the first, experimental stage of implementing cluster policy in Russia.

Government efforts have led to dozens of diverse clusters operating in various Russian regions by 2016, including innovative, industrial, agro-industrial, medical, and tourism clusters. In almost all regions where pilot ITCs are located, new clusters and cluster centres have emerged in the last three years. Accordingly, compared with 2012 the situation has now noticeably changed; hence, government policy needs to move to a new stage that includes the following steps:

${ }^{10}$ Other analytical methods can be applied to study emerging industries: see, for example, [Zemtsov, 2013]. 
- Conducting an audit of supported clusters to establish whether they act as innovation-promoting networks, or as regional lobbyists protecting the status quo of an outdated industry structure;

- Taking into account the reputation of clusters (networks) when making decisions about granting them public support;

- Adjusting the mechanism for providing support to innovative clusters: a) supporting joint projects by cluster participants; b) introducing requirements for private investment in every publicly supported joint project; c) linking joint projects up with relevant technology agendas (e.g. Russian S\&T Foresight, National Technology Imitative);

- Further integration of the cluster approach into industry promotion programmes of federal agencies that are responsible for de facto existing clusters (Ministry of Agriculture, Ministry of Communications, Ministry of Energy, and Ministry of Health).

Accordingly, further support to the third group of clusters should be provided only if they meet the new requirements described above.

\section{Conclusion}

The original contribution of this paper lies in its proposed approach to identify industries with a high clustering potential, namely in factoring in the degree of monopolization of regional markets to minimize distortions of the data by the activities of large companies. Moreover, we took into account an indicator of the number of companies to identify small and micro-companies for which there are no reliable data on revenues and number of employees.

We assessed the degree of match between the pilot ITCs supported with public funds and the actual regional entrepreneurial and competitive environment. Overall, the overwhelming majority of clusters selected by the Russian Ministry of Economic Development are located in regions with a high clustering potential in the relevant industries. At the same time, we also found some Russian regions with equivalent, or even more favourable, conditions for implementing a proactive cluster policy than in the selected regions. In particular, we showed that shipbuilding companies in the city of St. Petersburg, Astrakhan, Primorsky, and Kamchatka regions have a higher clustering potential compared to Archangel and Khabarovsk regions. Pharmaceutical clusters established in the city of St. Petersburg, Moscow, Tomsk, Kaluga, Novosibirsk, and Altai regions have potential competitors in the city of Moscow, Nizhny Novgorod region, and the Republic of Tatarstan.

Petrochemical clusters are supported in the Republics of Tatarstan and Bashkortostan and Nizhny Novgorod region, while Krasnodar and Samara regions' clustering potential is no less than that in Nizhny Novgorod region.

In addition to the information and communication technologies clusters that receive public support (the cities of Moscow and St. Petersburg, Tomsk, Moscow, Novosibirsk, and Nizhny Novgorod regions), Perm, Rostov, and Sverdlovsk regions also have high clustering potential in this industry and show comparable numbers of relevant companies generating similar revenues.

Aerospace clusters in the Perm and Ulyanovsk regions have lower clustering potential than in the capital areas of the cities of Moscow and St. Petersburg, and the Moscow region.

In the electronics industry, Technopolis GS in the region of Kaliningrad and relevant companies in Penza region did not receive government support, although they did apply for pilot ITC cluster status in 2012.

It should be noted that a condition of inclusion in the list of pilot ITCs was the presence of a coordinator organization capable of adequately preparing the application in a relatively short time frame. We believe that explains why certain promising clusters were not on the list approved by the Russian Ministry of Economic Development. This testifies not so much to the faulty selection methodology applied by the federal agency but rather to the low level of applicants' organizational abilities or the insufficient activity of regional authorities.

We divided all high-tech ITCs into three groups based on the value of their clustering potential index. The first group comprised pharmaceuticals, production of medical equipment and biotechnology, ICT, instrumentation engineering (production of electrical machinery), and electronics. The second group included the petrochemical industry, shipbuilding, coal industry, aircraft and spacecraft construction, propulsion engineering, and the automobile industry. The third group of industries included the production of new materials (e.g. the titanium cluster in Sverdlovsk region), nuclear, and radiation technologies.

Each of the three groups mentioned above require a specific kind of cluster policy. Industries of the first group would benefit from state support for new clusters, the engagement of 'sleeping' regions, and an 
extended set of regulatory tools. Policy recommendations for the second group of ITCs include adapting existing industries to future markets, restructuring production, and increasing the share of small and medium companies that make high-quality products. Clusters in the third group of ICTs require an audit to determine whether providing them with further public support would be sensible.

The limitations of our applied approach are due to the lack of statistical data, which significantly varies depending on the industry and company size. The bigger the company, the more official data about it available (all other conditions being equal). No data on many small and micro-companies' revenues and employment figures are available, the category to which most companies in the high-tech and emerging industries belong. Therefore, in our calculations we had to use data about all firms, not just small and medium ones. Arguably, the presence of large companies in a given region also enables clusters to be formed because of the emergence of spin-offs and the demand the former generate for small businesses' products. Certain errors arise with attributing ITCs to the OKVED classification of economic activity types. Many companies are classified as specializing in traditional industries although in fact they manufacture innovative products. For example, biotechnology companies engaged in genetic engineering are classified as producers of agricultural products. The opposite may also be true: many pharmaceutical firms, for example, are formally classified as high-tech companies, although they make no innovative products and actually make packaging for medicines. Furthermore, we also lack data for industries connected with national defence (e.g. shipbuilding, nuclear energy, production of communication equipment, etc.), which makes it impossible to apply our methodology to study clustering processes in these sectors.

In our calculations, we used the official registration addresses of legal entities and not the actual locations of production facilities. Hence, the city of Moscow's leading position as the Russian region with the highest clustering potential in certain industries is rather speculative.

In future, we intend to further develop our methodology by analysing the activities of educational and R\&D organizations in clusters' industrial specializations, and by assessing the links between various organizations. This would involve further research of cluster initiatives, including on the basis of the results of the above-mentioned 'Cluster Initiatives Map' project coordinated by the HSE.

The article has been prepared based on the results of a survey conducted under the auspices of the Basic Research Program of the National Research University HSE (NRU HSE), using subsidiary funds as part of state support for leading universities of the Russian Federation in the programme '5-100'.

\section{References}

Abashkin V., Boyarov A., Kutsenko E. (2012) Klasternaya politika v Rossii: ot teorii k praktike [Cluster Policy in Russia: From Theory to Practice]. Foresight-Russia, vol. 6, no 3, pp. 16-27 (in Russian).

Baburin V., Zemtsov S. (2013) Geografiya innovatsionnykh protsessov v Rossii [Geography of innovation processes in Russia]. MSU Vestnik (Series 5, Geography), no 5, pp. 25-32 (in Russian).

Bair J., Gereffi G. (2001) Local clusters in global chains: The causes and consequences of export dynamism in Torreon's blue jeans industry. World development, vol. 29, no 11, pp. 1885-1903.

Bortnik I., Zemtsov S., Ivanova O., Kutsenko E., Pavlov P, Sorokina A. (2015) Stanovlenie innovatsionnykh klasterov v Rossii: itogi pervykh let podderzhki [The innovation clusters development in Russia: The achievements of the first years of support]. Innovatsii [Innovations], no 7, pp. 26-36 (in Russian).

Bresnahan T., Gambardella A., Saxenian A. (2001) 'Old economy' inputs for 'new economy' outcomes: Cluster formation in the new Silicon Valleys. Industrial and Corporate Change, vol. 10, № 4, pp. 835-860.

Christensen T.A., Lämmer-Gamp T., Meier zu Kôcker G. (2012) Let's make a perfect cluster policy and cluster programme. Smart recommendations for policy makers, Berlin: VDI/VDE Innovation + Technik GmbH (VDI/ VDE-IT).

Cooke P., Schwartz D. (eds.) (2007) Creative Regions. Technology, Culture and Knowledge Entrepreneurship, London: Routledge.

Danko T., Kutsenko E. (2012) Osnovnye podkhody k vyyavleniyu klasterov v ekonomike regiona [The main approaches to the regional clusters identification]. Problemy sovremennoi ekonomiki [Problems of Modern Economics], no 1, pp. 248-254 (in Russian).

Delgado M., Porter M.E., Stern S. (2014) Defining clusters of related industries (NBER Working Paper no 20375), Cambridge, MA: National Bureau of Economic Research. Available at: http://www.nber.org/papers/w20375, accessed 17.01.2016

DGCIS (2009) Competitiveness Clusters in France, Paris: Directorate General for Competitiveness, Industry and Services. Available at: http://www.industrie.gouv.fr/poles-competitivite/brochure-en.html, accessed 05.06.2016.

Dohse D., Staehler T. (2008) BioRegio, BioProfile and the Rise of the German Biotech Industry (Working Paper no 1456), Kiel: Kiel Institute for the World Economy. Available at: http://www.ifw-members.ifw-kiel.de/publications/ bioregio-bioprofile-and-the-growth-of-the-german-biotech-industry/KWP_1456.pdf, accessed 05.06.2016.

Duranton G. (2011) California Dreamin': The Feeble Case for Cluster Policies. Review of Economic Analysis, no 3, pp. 3-45.

Eickelpasch A. (2008) The Promotion of Regional Innovative Networks - Lessons from the German InnoRegioProgramme. Paper presented at the Innovation Pathways and Knowledge Economy, Final DISTRICT Conference, 16.04.2008, Brussels.

Feldman M., Francis J., Bercovitz J. (2005) Creating a cluster while building a firm: Entrepreneurs and the formation of industrial clusters. Regional Studies, vol. 39, no 1, pp. 129-141. 
Gokhberg L., Shadrin A. (2015) Pilotnye innovatsionnye territorial'nye klastery v Rossiiskoi Federatsii. Vypusk 2. Napravleniya realizatsii programm razvitiya [Pilot innovative territorial clusters in the Russian Federation. Issue 2. The development programs implementation guidelines], Moscow: HSE (in Russian).

Hagenauer S., Kergel H., Stürzebecher D. (2012) European Cluster Excellence BASELINE - Minimum Requirements for Cluster Organisations, Stuttgart: European Cluster Excellence Initiative. Available at: http://www.clusterexcellence.eu/fileadmin/cluster-excellence/grafiken/20111128_European_Cluster_Excellence_BASELINE_web. pdf, accessed 05.06.2016.

INNO Germany AG (2010) Clusters and clustering policy: A guide for regional and local policy makers, Brussels: European Commission. Available at: http://cor.europa.eu/en/Archived/Documents/59e772fa-4526-45c1-b6791da3bae37f72.pdf, accessed 05.06.2016.

Karlsson C. (2008) Handbook of Research on Cluster Theory, Cheltenham: Edward Elgar.

Ketels C. (2003) The Development of the cluster concept - Present experiences and further developments. Paper presented at the NRW Conference on Clusters, Duisburg, Germany. Available at: http://www.clustermapping.us/ sites/default/files/files/resource/The_development_of_the_cluster_concept_-_present_experiences_and_further_ developments.pdf, accessed 14.07.2016.

Ketels C., Lindqvist G., Sölvell Ö. (2012) Strengthening Clusters and Competitiveness in Europe. The Role of Cluster Organisations, Stockholm: Cluster Observatory.

Ketels C., Protsiv S. (2014a) European Cluster Panorama 2014, Stockholm: Cluster Observatory. Available at: http:// antonioviader.com/pdfs_preview/userupload/toni/Innovation_Policies/Metrics_Monitoring/EC\%20Cluster\%20 Panorama\%202014.pdf, accessed 05.06.2016.

Ketels C., Protsiv S. (2014b) Methodology and Findings Report for a Cluster Mapping of Related Sectors, Stockholm: Cluster Observatory. Available at: http://ec.europa.eu/enterprise/initiatives/cluster/observatory/d1, accessed 05.06.2016.

Kutsenko E. (2009) Klastery v ekonomike: praktika vyyavlenija. Obobshcheniye zarubezhnogo opyta [The practice of identifying clusters in the economy: The summary of the international practices]. Obozrevatel [Observer], no 10 (237), pp.109-126 (in Russian).

Kutsenko E. (2012) Ratsionalnaya klasternaya strategiya: manevriruya mezhdu provalami rynka i gosudarstva [A Rational Cluster Strategy: Manoeuvring between Market and Government Failures]. Foresight-Russia, vol. 6, no 3, pp. 6-15 (in Russian).

Kutsenko E. (2015) Pilot Innovative Territorial Clusters in Russia: A Sustainable Development Model. ForesightRussia, vol. 9, no 1, pp. 32-55.

Kutsenko E., Kiselev A., Karnaukh A. (2011) Opredeleniye prioritetnykh napravlenii dlya formirovaniya i razvitiya klasterov malykh i srednikh predpriyatii $\mathrm{v}$ regional'noi ekonomike (na primere goroda Moskvy) [The priority directions for SMEs clusters development identification in the regional economy (the Moscow city case)]. Setevoi biznes i klasternyje tekhnologii [Network business and cluster technologies], Moscow: HSE, pp. 279-302 (in Russian).

Landry C. (2008) The Creative City: A Toolkit for Urban Innovators (2nd ed.), London: Earthscan.

Lindqvist G., Ketels C., Sölvell Ö. (2013) The Cluster Initiative Greenbook 2.0, Stockholm: Ivory Tower Publishers.

Marshall A. (1920) Principles of Economics (revised ed.), London: Macmillan; reprinted by Prometheus Books.

Martin P., Mayer T., Mayneris F. (2008) Spatial concentration and firm-level productivity in France (CEPR Discussion Paper no 6858), London: Centre for Economic Policy Research.

Pamminger W. (2014) Cluster Academy Workshop: Learning from a 'Cluster Region'. Available at: http://www. slideshare.net/TCINetwork/tci2014-11-novclusterlabswerner-pamminger, accessed 05.06.2015.

PilipenkoI. (2004) Printsipial'nyerazlichiya vkontseptsii promyshlennykh klasteroviterritorial'no-proizvodstvennykh kompleksov [The principal differences of the industrial clusters and territorial production complexes' concepts]. MSU Vestnik (Series 5, Geography), no 5, pp. 3-9 (in Russian).

Porter M.E. (1998) Cluster and the New Economics of Competition. Harvard Business Review, vol. 76, no 6, pp. 77-90.

Porter M.E. (2003) The economic performance of regions. Regional Studies, vol. 37, no 6-7, pp. 545-546.

Porter M.E. (2008) On Competition, Boston, MA: Harvard Business Press.

Porter M.E., Ketels C.H.M. (2007) Competitiveness at the Crossroads: Choosing the Future Direction of the Russian Economy, Moscow: Center for Strategic Research. Available at: http://www.hbs.edu/faculty/Publication\%20 Files/Russia_Competitiveness_Crossroads_Dec2007_2423559d-9d53-4b95-b206-28d6208f851a.pdf, accessed 09.11.2015.

Pro Inno Europe (2009) INNO-PolicyTrendChart. Available at: http://proinno.intrasoft.be/index.cfm?fuseaction=wiw. measures\&page $=$ detail\&ID=8922, accessed 05.06.2015.

Rosstat (2014) Metodika rascheta pokazatelei "Dolya produktsii vysokotekhnologichnykh i naukoyomkikh otraslei v valovom vnutrennem produkte" $i$ "Dolya produktsii vysokotekhnologichnykh $i$ naukoyomkikh otraslei $v$ valovom regional'nom produkte subjekta Rossiiskoi Federatsii" [The calculation methodology of the indicators "The share of high-tech and knowledge-intensive industries in the gross domestic product" and "The calculation methodology of the indicators "The share of high-tech and knowledge-intensive industries in the gross regional product of the Russian Federation"]. Available at: http://www.gks.ru/free_doc/new_site/effect/met_pr21.docx, accessed 05.06.2016 (in Russian).

Sörvik J., Midtkandal I. (2013) Smart Specialisation in the Baltic Sea Region, Malmö: S3 Platform, DG JRC - IPTS.

Staber U. (2001) Spatial Proximity and Firm Survival in a Declining Industrial District: The Case of Knitwear Firms in Baden-Wurttemberg. Regional Studies, vol. 35, no 4, pp. 329-341.

van der Linde C. (2003) The Demography of Clusters - Findings from the Cluster Metastudy. Innovation Clusters and Interregional Competition (eds. J. Bröcker, D. Dohse, R. Soltwedel), Berlin: Springer Verlag, pp. 130-149.

Wennberg K., Lindqvist G. (2010) The effect of clusters on the survival and performance of new firms. Small Business Economics, vol. 34, no 3, pp. 221-241.

Zemtsov S. (2013) Opyt vyavleniya i otsenki potentsiala innovatsionnykh klasterov (na primere otrasli "Ratsionalnoe prirodopolzovaniye") [Efforts to identify and evaluate the potential of innovative clusters]. Regionalnyie issledovaniya [Regional Research], no. 2, pp. 12-19 (in Russian).

Zemtsov S., Bukov D. (2016) Metody vyyavlenia klasterov malogo i srednego biznesa [The small and medium enterprises clusters' identification]. Regional'naya ekonomika: teoriya I praktika [Regional Economics: Theory and Practice], no. 3, pp. 104-117 (in Russian).

Zemtsov S.P., Barinova V.A., Bukov D.V., Eremkin V.A. (2015) Uncovering Regional Clustering of High Technology SMEs: Russian Case. Mediterranean Journal of Social Sciences, no. 6, pp. 309-320.

Zhang S., Li X. (2008) Managerial ties, firm resources, and performance of cluster firms. Asia Pacific Journal of Management, vol. 25, no. 4, pp. 615-633. 